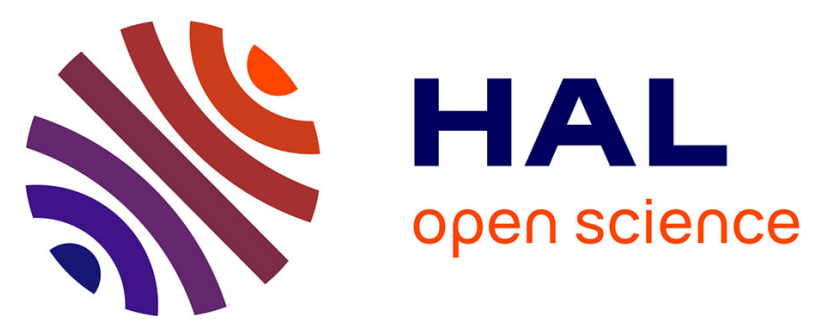

\title{
Poly(arylene vinylene) Synthesis via a Precursor Step-Growth Polymerization Route Involving the Ramberg-Bäcklund Reaction as a Key Post-Chemical Modification Step
}

Kunche Aravindu, Eric Cloutet, Cyril Brochon, Georges Hadziioannou, Joan

Vignolle, Frédéric Robert, Daniel Taton, Yannick Landais

\section{To cite this version:}

Kunche Aravindu, Eric Cloutet, Cyril Brochon, Georges Hadziioannou, Joan Vignolle, et al.. Poly(arylene vinylene) Synthesis via a Precursor Step-Growth Polymerization Route Involving the Ramberg-Bäcklund Reaction as a Key Post-Chemical Modification Step. Macromolecules, 2018, 51 (15), pp.5852 - 5862. 10.1021/acs.macromol.8b00676 . hal-01858135

\section{HAL Id: hal-01858135 https://hal.science/hal-01858135}

Submitted on 8 Jan 2021

HAL is a multi-disciplinary open access archive for the deposit and dissemination of scientific research documents, whether they are published or not. The documents may come from teaching and research institutions in France or abroad, or from public or private research centers.
L'archive ouverte pluridisciplinaire HAL, est destinée au dépôt et à la diffusion de documents scientifiques de niveau recherche, publiés ou non, émanant des établissements d'enseignement et de recherche français ou étrangers, des laboratoires publics ou privés. 


\title{
Poly(arylene vinylene) Synthesis via a Precursor Step-growth Polymerization Route Involving the Ramberg-Bäcklund Reaction as a Key Post-chemical Modification Step
}

\author{
Kunche Aravindu, ${ }^{1,2}$ Eric Cloutet, ${ }^{2}$ Cyril Brochon, ${ }^{2}$ Georges Hadziioannou, ${ }^{2}$ Joan Vignolle, ${ }^{2}$ Frédéric \\ Robert, ${ }^{1}$ Daniel Taton, ${ }^{2 *}$ Yannick Landais ${ }^{1 *}$ \\ ${ }^{1}$ Institute of Molecular Sciences, UMR-CNRS 5255, University of Bordeaux, \\ 351 Cours de la libération, 33405 Talence cedex, France \\ ${ }^{2}$ Laboratoire de Chimie des Polymères Organiques (LCPO UMR 5629), CNRS-Université de \\ Bordeaux-Bordeaux INP, 16 Avenue Pey-Berland, 33607 Pessac cedex, France
}

Corresponding Author*: E-Mails: taton@enscbp.fr and yannick.landais@u-bordeaux.fr

Keywords: Ramberg-Bäcklund reaction, Poly(fluorene vinylene), Poly(fluorene vinylene-co-carbazole vinylene), Step-growth polymerization, $\pi$-Conjugated polymers

\begin{abstract}
The synthesis of conjugated copolymers based on poly(fluorene vinylene) [PFV] and poly(fluorene vinylene-co-carbazole vinylene) [PFVCV] was achieved via a previously unexplored precursor three-step synthetic route involving the Ramberg-Bäcklund reaction. The resulting $\pi$ conjugated (co)polymers proved highly soluble in common organic solvents, such as DCM, THF, or $\mathrm{CHCl}_{3}$. The solution step-growth polymerization between 2,7-bis(bromomethyl)-9,9'-dihexyl-9Hfluorene [F-Br] and 2,7-bis(mercaptomethyl)-9,9'-dihexyl-9H-fluorene [F-SH] was carried out under basic conditions at $100{ }^{\circ} \mathrm{C}$ in a mixture of $\mathrm{MeOH}$ and THF. The resulting polysulfides were then subjected to an oxidation reaction using $m$-CPBA, which was followed by the Ramberg-Bäcklund reaction in the presence of $\mathrm{CF}_{2} \mathrm{Br}_{2} / \mathrm{Al}_{2} \mathrm{O}_{3}-\mathrm{KOH}$, thus achieving the desired PFV. Similarly, PFVCV could be synthesized through the same three-step sequence employing, in this case, 2,7bis(mercaptomethyl)-9-(tridecan-7-yl)-9H-carbazole (C-SH) and F-Br. Conjugated polymers with apparent molecular weights up to $15 \mathrm{~kg} \cdot \mathrm{mol}^{-1}$ and exhibiting promising optical features were obtained following this convenient synthetic strategy.
\end{abstract}




\section{INTRODUCTION}

In recent years, thin-film device technologies employing $\pi$-conjugated polymers have attracted a great deal of attention owing to their properties suitable for electronic and optoelectronic applications, including organic transistors, ${ }^{1-2}$ bulk heterojunction solar cells for organic photovoltaics $(\mathrm{OPV})^{3-4}$ or organic light emitting diodes (OLED). ${ }^{5}$ The solution-processability of $\pi$-conjugated polymers, combined with their optoelectronic properties, such as light absorption, carrier mobility and exciton dynamics, can be fine-tuned through subtle changes in their structure. Molecular parameters include molecular weight, bond length alternation, substituent effects, aromaticity, planarity, regioregularity, intermolecular interactions, etc. Hence, simple synthetic modifications can dramatically impact optoelectronic and thin film self-assembled properties. Most $\pi$-conjugated polymers consist of $\mathrm{sp}^{2}$-hybridized carbon atoms and are based on aryl-aryl or aryl-vinyl repeating units, mostly through alternation between $\mathrm{C}-\mathrm{C}$ and $\mathrm{C}=\mathrm{C}$ bonds. ${ }^{6}$ Heteroatoms can be introduced in the $\pi$-conjugation system: for instance, the $-\mathrm{C}=\mathrm{N}$ - double bond is somehow electrically equivalent to the $-\mathrm{C}=\mathrm{C}$ - one.

In this context, poly( $p$-phenylene vinylene)- (PPV)-type $\pi$-conjugated polymers represent a special class of highly fluorescent, highly stable polymeric semiconductors. ${ }^{7-8}$ PPV-like materials can be synthesized by a wide variety of synthetic routes, either following a step-growth or a chain-growth polymerization pathway. Step-growth polymerization methods directly leads to PPV oligomers and rely on well-established elementary reactions of molecular chemistry, such as the Knoevenagel condensation, ${ }^{8}$ the Wittig or Horner-Wadsworth-Emmons olefination, ${ }^{9,10,11}$ the palladium-catalyzed Stille, Suzuki or Heck coupling ${ }^{12}$ and the Siegrist reaction. ${ }^{13}$ Alternatively, chain-growth polymerization methods allow achieving higher molecular weights. However, the final PPV material is often obtained by post-chemical modification of a polymer precursor as for instance in Gilch, ${ }^{14}$ Wessling sulfonium, ${ }^{15-}$ ${ }^{16}$ dithiocarbamate (or xanthate), and sulfinyl routes. ${ }^{17-18}$ In order to alleviate solubility issues and facilitate their processability, specific groups can be introduced in 2- and 5-positions of the aromatic ring of PPV-type materials. Controlled living polymerization has also been considered for PPV synthesis. ${ }^{19}$ With the exception of PPV's grown both by the latter method under specific conditions and by ringopening metathesis polymerization (ROMP), relatively poor control over molecular weights and dispersities generally characterize these polymerization routes. More generally, these synthetic methods to PPV's, although straightforward, still show some limitations, including: (a) structural defects due to incomplete post-chemical modification by thermal conversion or oxidation (b) modest molecular weights (c) generation of toxic side products during the elimination process (d) gelation or precipitation of the polymeric products, which may occur during polymerization (e) limited control over the $E / Z$ content of the vinyl bridge (f) use of costly and non-renewable metal catalysts and, last but not least, (g) the presence of residual metallic traces, which require lengthy and tedious purification steps. ${ }^{20}$

On this basis, we envisioned developing novel PPV-like materials following a previously unexplored precursor step-growth polymerization route/post-chemical functionalization sequence, involving a threestep sequence of reactions (Figure 1). The first step (i) is achieved by step-growth polymerization in solution of dibromides and dithiols as monomers, forming polysulfides. The second step (ii) consists in oxidizing these polymer precursors into polysulfones, which is followed by an ultimate step (iii) of elimination, via the so-called Ramberg-Bäcklund reaction. ${ }^{21}$ The Ramberg-Bäcklund reaction is very versatile for the construction of carbon-carbon double bonds, and has been largely applied in the context 
of total synthesis of complex natural products. Only recent reports have described its application in dendrimer synthesis. ${ }^{22}$ This reaction involves a suitably designed sulfone precursor, which upon $\alpha$ halogenation under basic conditions, provides the corresponding olefin generally in high yields. It is thus a simple way to create $\mathrm{C}=\mathrm{C}$ double bonds under mild conditions, starting from readily available substrates. Another advantage of this process is that it allows the coupling around the sulfonyl group of identical or differentiated substituents, on purpose, in a limited number of steps. Starting materials are easily available and provide olefins without alkene rearrangements under mild alkaline conditions. E/Zstereocontrol mainly relies on the nature of the base, with mild bases favoring the $Z$-isomer, while $E$ - is generally formed in the presence of stronger bases. Many examples have demonstrated that the RambergBäcklund process can be applied to the preparation of polysubstituted alkenes, including tetrasubstituted ones as well as polyenes. ${ }^{21}$ Iterative synthesis of oligo-PPV's has been described, ${ }^{23-24}$ but to the best of our knowledge, this reaction has never been applied to the synthesis of polyolefins starting from polysulfones. The synthetic approach we devise here opens a general and straightforward access to symmetrical PPV-like materials bearing identical aromatic fragments (Route A, Figure 1). By varying the nature of aryl groups, the optoelectronic properties could be tuned depending on the targeted application (OPV, OLED ...). ${ }^{25-26}$ Furthermore, the conjunctive nature of the Ramberg-Bäcklund process should be particularly appealing for the design of alternating monomer units along the $\pi$-conjugated backbone (Route B, Figure 1). For example, it could allow the formation of "donor-acceptor" alternating low band gap copolymers, by using electron-rich and electron-poor monomer units. Such copolymers are characterized by an extended optical absorption to the red region, and allow for a better manipulation of the HOMO/LUMO levels, providing conjugated systems with relatively high charge carrier mobility. ${ }^{27-31}$

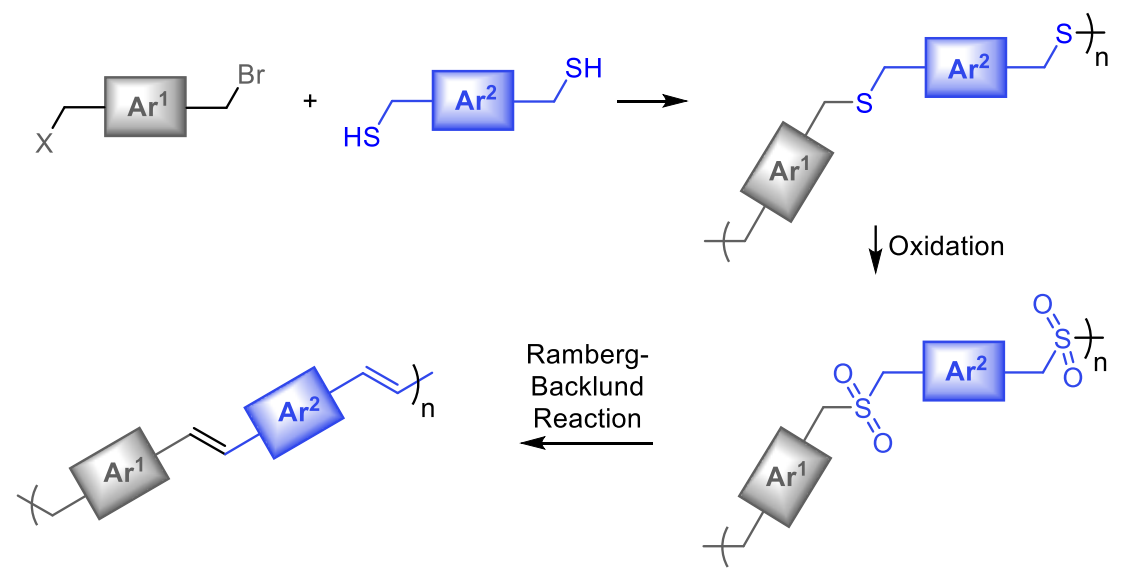

Route A: symmetrical poly(arylene vinylene) (PArV): $\mathrm{Ar}^{1}=\mathrm{Ar}^{2}$

Route B: Alternated poly(arylene vinylene) $\left(\mathrm{PAr}^{1,2} \mathrm{~V}\right): \mathrm{Ar}^{1} \neq \mathrm{Ar}^{2}$

Figure 1. Synthetic strategies toward poly(arylene vinylene)s (PPV's) based on the Ramberg-Bäcklund reaction.

As an example of the potentiality of these arylene-vinylene polymers, recently, Nomura and coll. have obtained PPV's with different end-groups by combining acyclic diene metathesis polymerization with Wittig-type couplings. ${ }^{32,33}$ Here we describe the synthetic developments validating both strategies, by reporting the synthesis of poly(fluorene vinylene)- and poly(fluorene-carbazole vinylene)-type conjugated (co)polymers. 


\section{EXPERIMENTAL SECTION}

All reactions were carried out under an argon atmosphere with solvents dried over activated alumina columns on MBraun Solvent Purification System (SPS-800), unless otherwise noted.

All reagent-grade chemicals were obtained from commercial suppliers and were used as received, unless otherwise stated. ${ }^{1} \mathrm{H}$ NMR and ${ }^{13} \mathrm{C}$ NMR were recorded on various spectrometers: a Brüker Avance 300 $\left({ }^{1} \mathrm{H}: 300 \mathrm{MHz},{ }^{13} \mathrm{C}: 75.46 \mathrm{MHz}\right)$, a Brüker Avance $400\left({ }^{1} \mathrm{H}: 400 \mathrm{MHz},{ }^{13} \mathrm{C}: 100.6 \mathrm{MHz}\right)$ using $\mathrm{CDCl}_{3}$ as internal reference unless otherwise indicated. The chemical shifts $(\delta)$ and coupling constants $(J)$ are expressed in ppm and $\mathrm{Hz}$ respectively. The following abbreviations were used to explain the multiplicities: $\mathrm{s}=$ singlet, $\mathrm{d}=$ doublet, $\mathrm{t}=$ triplet, $\mathrm{q}=$ quartet, $\mathrm{m}=$ multiplet, $\mathrm{br}=$ broad. FT-IR spectra were recorded on a Perkin-Elmer Spectrum 100 using a diamond ATR accessory. High-resolution mass spectra (HRMS) were recorded with a Waters QTOF 2 spectrometer in the electrospray ionization (ESI) mode. Melting points were not corrected and determined by using a Stuart Scientific SMP3 apparatus. Analytical thin layer chromatography was performed using silica gel 60 F254 pre-coated plates (Merck) with visualization by ultraviolet light, potassium permanganate. Flash chromatography was performed on silica gel (0.043-0.063 mm) with ethyl acetate (EtOAc) and petroleum ether (PE) as eluents unless otherwise indicated.

2,7-Bis(hydroxymethyl)-9,9'-dihexyl-9H-fluorene (2). To a stirred solution of 9,9'-dihexyl-9Hfluorene-2,7-dicarbaldehyde $\mathbf{1}^{34}(4.29 \mathrm{~g}, 11 \mathrm{mmol})$ in a 3:1 THF/MeOH mixture $(100 \mathrm{~mL}), \mathrm{NaBH}_{4}(3.34$ $\mathrm{g}, 88 \mathrm{mmol}$ ) was added portion wise at $0{ }^{\circ} \mathrm{C}$ and then the reaction mixture was allowed to warm to room temperature for $4 \mathrm{~h}$. The reaction was quenched with aq. $\mathrm{NH}_{4} \mathrm{Cl}$ solution $(10 \mathrm{~mL})$, and the aqueous layer extracted with ethyl acetate $(2 \times 50 \mathrm{~mL})$. The organic layer was then dried over anhydrous $\mathrm{Na}_{2} \mathrm{SO}_{4}$ and solvents evaporated to give a crude mixture which was purified by flash column chromatography (silica, EtOAc/PET 1:9), affording the desired compound as a white solid (3.46 g, 80\%). The spectral data are consistent with those reported in the literature. ${ }^{35}$

$\mathrm{Mp}=74-76^{\circ} \mathrm{C}$; IR (ATR) $v_{\max }\left(\mathrm{cm}^{-1}\right): 3285,2925,2854,1457 ;{ }^{1} \mathrm{H}$ NMR $\left(300 \mathrm{MHz}, \mathrm{CDCl}_{3}\right): \delta 0.52-0.68$ $(\mathrm{m}, 4 \mathrm{H}), 0.70-0.82(\mathrm{~m}, 6 \mathrm{H}), 0.94-1.18(\mathrm{~m}, 12 \mathrm{H}), 1.88(\mathrm{br}, 2 \mathrm{H}), 1.90-2.02(\mathrm{~m}, 4 \mathrm{H}), 4.75(\mathrm{~s}, 4 \mathrm{H}), 7.27-7.36$ $(\mathrm{m}, 4 \mathrm{H}), 7.62-7.70(\mathrm{~m}, 2 \mathrm{H}) ;{ }^{13} \mathrm{C} \mathrm{NMR}\left(75 \mathrm{MHz}, \mathrm{CDCl}_{3}\right): \delta 13.97,22.56,23.71,29.67,31.47,40.32$, 54.99, 65.72, 119.64, 121.49, 125.73, 139.74, 140.35, 151.30; HRMS: Calcd. for $\mathrm{C}_{27} \mathrm{H}_{38} \mathrm{O}_{2}[\mathrm{M}]^{+}$. 394.28718, found 394.28862.

2,7-Bis(bromomethyl)-9,9'-dihexyl-9H-fluorene (F-Br). To a stirred solution of 2 (1.54 g, $3.91 \mathrm{mmol})$ in benzene $(20 \mathrm{~mL}), \mathrm{PBr}_{3}(1.09 \mathrm{~mL}, 11.7 \mathrm{mmol})$ was slowly added at room temperature, then the reaction mixture was heated to $45^{\circ} \mathrm{C}$ for $6 \mathrm{~h}$. The reaction was quenched with water $(10 \mathrm{~mL})$ and extracted with dichloromethane $(2 \times 25 \mathrm{~mL})$. The organic layer was dried over anhydrous $\mathrm{Na}_{2} \mathrm{SO}_{4}$ and solvents evaporated to give a crude mixture which was purified by flash column chromatography (silica, $\mathrm{CH}_{2} \mathrm{Cl}_{2} / \mathrm{PET} \mathrm{1:9)}$ to afford the compound $\mathbf{F}-\mathbf{B r}$ as a white solid (1.21 g, 59\%). The spectral data are consistent with literature data. ${ }^{35}$

$\mathrm{Mp}=51-53^{\circ} \mathrm{C}$; IR (ATR) $v_{\max }\left(\mathrm{cm}^{-1}\right): 2924,1468,1291 ;{ }^{1} \mathrm{H} \mathrm{NMR}\left(300 \mathrm{MHz}, \mathrm{CDCl}_{3}\right): \delta 0.53-0.68(\mathrm{~m}$, $4 \mathrm{H}), 0.70-0.82(\mathrm{~m}, 6 \mathrm{H}), 0.95-1.18(\mathrm{~m}, 12 \mathrm{H}), 1.90-2.02(\mathrm{~m}, 4 \mathrm{H}), 4.59(\mathrm{~s}, 4 \mathrm{H}), 7.32-7.39(\mathrm{~m}, 4 \mathrm{H}), 7.59-$ $7.68(\mathrm{~m}, 2 \mathrm{H}) ;{ }^{13} \mathrm{C} \mathrm{NMR}\left(75 \mathrm{MHz}, \mathrm{CDCl}_{3}\right): \delta 13.98,22.46,23.61,29.51,31.34,34.43,40.05,55.11$, 120.03, 123.64, 127.98, 136.86, 140.71, 151.63; HRMS: Calcd. for $\mathrm{C}_{27} \mathrm{H}_{36} \mathrm{Br}_{2}[\mathrm{M}]^{+.}$518.11838, found 518.12470 . 
2,7-Bis(mercaptomethyl)-9,9'-dihexyl-9H-fluorene (F-SH). Following a slightly modified literature procedure, ${ }^{36}$ to a stirred solution of F-Br $(1.04 \mathrm{~g}, 2 \mathrm{mmol})$ in EtOH $(10 \mathrm{~mL})$, thiourea $(0.334 \mathrm{~g}, 4.40$ $\mathrm{mmol}$ ) was added and the reaction mixture was heated to reflux for $4 \mathrm{~h}$. Then, the solvent was evaporated under vacuum, the solid obtained was hydrolyzed with $50 \%$ aqueous sodium hydroxide solution $(10 \mathrm{~mL})$ and extracted with EtOAc $(2 \times 25 \mathrm{~mL})$. The organic layer was dried over anhydrous $\mathrm{Na}_{2} \mathrm{SO}_{4}$, and solvents evaporated to give a crude mixture, which was purified by flash column chromatography (silica, $\mathrm{CH}_{2} \mathrm{Cl}_{2}$ /PET 3:7) to afford the desired compound F-SHas a white solid (0.42 g, 49\%).

mp: $39-41^{\circ} \mathrm{C}$; IR (ATR) $v_{\max }\left(\mathrm{cm}^{-1}\right): 2925,2556,1520 ;{ }^{1} \mathrm{H}$ NMR $\left(300 \mathrm{MHz}, \mathrm{CDCl}_{3}\right): \delta$ 0.54-0.68 (m, $4 \mathrm{H}), 0.76(\mathrm{t}, 6 \mathrm{H}, J=6.9 \mathrm{~Hz}), 0.95-1.18(\mathrm{~m}, 12 \mathrm{H}), 1.77(\mathrm{t}, 2 \mathrm{H}, J=7.5 \mathrm{~Hz}), 1.86-1.98(\mathrm{~m}, 4 \mathrm{H}), 3.82(\mathrm{~d}$, $4 \mathrm{H}, J=7.5 \mathrm{~Hz}), 7.22-7.30(\mathrm{~m}, 4 \mathrm{H}), 7.54-7.62(\mathrm{~m}, 2 \mathrm{H}) ;{ }^{13} \mathrm{C} \mathrm{NMR}\left(75 \mathrm{MHz}, \mathrm{CDCl}_{3}\right): \delta 13.98,22.49$, 23.64, 29.37, 29.57, 31.37, 40.15, 54.95, 119.63, 122.48, 126.69, 139.69, 139.91, 151.34; HRMS: Calcd. for $\mathrm{C}_{27} \mathrm{H}_{38} \mathrm{~S}_{2}[\mathrm{M}]^{+\cdot}$ 426.24149, found 426.24213.

Synthesis of PF-S. In a sealed tube, a solution of F-Br (1.04 g, $2 \mathrm{mmol})$ and F-SH (0.85 g, $2 \mathrm{mmol})$ in a 1:1 THF/MeOH mixture $(20 \mathrm{~mL})$ was treated with powdered $\mathrm{KOH}(0.34 \mathrm{~g}, 6 \mathrm{mmol})$ and the reaction mixture was heated to $100{ }^{\circ} \mathrm{C}$ for $14 \mathrm{~h}$. Then, the reaction mixture was cooled to room temperature and the solvent evaporated under vacuum. The crude reaction mixture was washed with $\mathrm{H}_{2} \mathrm{O}(20 \mathrm{~mL}), \mathrm{MeOH}$ $(20 \mathrm{~mL})$ and the solid filtered. The latter was then dissolved in $\mathrm{CHCl}_{3}(5 \mathrm{~mL})$ and purified by precipitation using $\mathrm{MeOH}(100 \mathrm{~mL})$, to provide the desired compound (PF-S) as a pale yellow solid $(1.27 \mathrm{~g}, 78 \%)$. IR (ATR) $v_{\max }\left(\mathrm{cm}^{-1}\right): 2923,2852,1465,817,748 ;{ }^{1} \mathrm{H}$ NMR $\left(300 \mathrm{MHz}, \mathrm{CDCl}_{3}\right): \delta$ 0.52-0.83 (m, 10H), 0.90-1.21 (m, 12H), 1.88-2.12 (m, 4H), $3.68(\mathrm{~s}, 4 \mathrm{H}), 7.19-7.35(\mathrm{~m}, 4 \mathrm{H}), 7.56-7.70(\mathrm{~m}, 2 \mathrm{H}) ;{ }^{13} \mathrm{C}$ NMR $\left(75 \mathrm{MHz}, \mathrm{CDCl}_{3}\right): \delta 13.98,22.52,23.82,29.74,31.56,35.50,40.54,54.96,119.56,123.42,127.89$, $136.84,139.87,150.97$; $\lambda_{\max }: 290,316 \mathrm{~nm}$.

Synthesis of PF-SO. A stirred solution of PF-S $(0.98 \mathrm{~g}, 2.5 \mathrm{mmol})$ in $\mathrm{CHCl}_{3}(50 \mathrm{~mL})$ was treated with $m$-CPBA $(2.16 \mathrm{~g}, 12.5 \mathrm{mmol})$ and the reaction mixture was stirred at room temperature for $8 \mathrm{~h}$. Then the reaction mixture was filtered and washed with $\mathrm{CHCl}_{3}$. The filtrate was washed with saturated aqueous $\mathrm{NaHCO}_{3}(2 \times 25 \mathrm{~mL})$, brine and water respectively. The organic solvent was evaporated and the crude compound thus obtained was purified by precipitation in a large excess of cold $\mathrm{MeOH}$ from a $\mathrm{CHCl}_{3}$ solution, to afford the desired polymer as a brown solid $(0.67 \mathrm{~g}, 63 \%)$.

IR (ATR) $v_{\max }\left(\mathrm{cm}^{-1}\right): 2924,2853,1467,1316,1150,612 ;{ }^{1} \mathrm{H}$ NMR $\left(300 \mathrm{MHz}, \mathrm{CDCl}_{3}\right): \delta 0.57-0.77(\mathrm{~m}$, $10 \mathrm{H}), 0.95-1.15(\mathrm{~m}, 12 \mathrm{H}), 1.96-2.13(\mathrm{~m}, 4 \mathrm{H}), 4.20(\mathrm{~s}, 4 \mathrm{H}), 7.35(\mathrm{~d}, 2 \mathrm{H}, J=7.8 \mathrm{~Hz}), 7.44(\mathrm{~s}, 2 \mathrm{H}), 7.76$ $(\mathrm{d}, 2 \mathrm{H}, J=7.8 \mathrm{~Hz}) ;{ }^{13} \mathrm{C}$ NMR $\left(75 \mathrm{MHz}, \mathrm{CDCl}_{3}\right): \delta 13.93,22.46,23.91,29.62,31.50,40.24,55.40,58.18$, $120.43,125.37,126.70,129.89,141.15,151.67 ; \lambda_{\max }: 290,316 \mathrm{~nm}$.

PF-SO via the rongalite ${ }^{\circledR}$ route. A mixture of F-Br $(0.26 \mathrm{~g}, 0.5 \mathrm{mmol})$, rongalite ${ }^{\circledR}(0.3 \mathrm{~g}, 2.5 \mathrm{mmol})$, $\mathrm{K}_{2} \mathrm{CO}_{3}(0.34 \mathrm{~g}, 2.5 \mathrm{mmol})$ and tetra- $n$-butylammonium bromide (TBAB) $(0.08 \mathrm{~g}, 0.25 \mathrm{mmol})$ in DMF $(2.5 \mathrm{~mL})$ was stirred at room temperature for 3 days. Water $(5 \mathrm{~mL})$ was then added to the reaction mixture. The resulting solid was filtered and washed with water $(10 \mathrm{~mL})$ and $\mathrm{MeOH}(10 \mathrm{~mL})$. The crude compound thus obtained was purified by precipitation in a large excess of cold $\mathrm{MeOH}$ from a $\mathrm{CHCl}_{3}$ solution, to obtain the PF-SO $(0.078 \mathrm{~g}, 37 \%)$ as a white solid. The spectral data ( $\left.{ }^{1} \mathrm{H} \mathrm{NMR}\right)$ are consistent with the earlier data.

Synthesis of PFV. In a sealed round bottom flask, a stirred solution of PF-SO (0.20 g, $0.47 \mathrm{mmol})$ in a 1:1 $\mathrm{THF} / t-\mathrm{BuOH}$ mixture $(10 \mathrm{~mL})$ was treated with freshly prepared $\mathrm{Al}_{2} \mathrm{O}_{3}-\mathrm{KOH}(1 \mathrm{~g})$ at $0^{\circ} \mathrm{C}$ and then 
$\mathrm{CF}_{2} \mathrm{Br}_{2}(1 \mathrm{~mL})$ was added at the same temperature. The reaction mixture was then stirred at room temperature for $24 \mathrm{~h}$. The reaction mixture was filtered through celite and washed with $\mathrm{CH}_{2} \mathrm{Cl}_{2}$. The solvent was evaporated and the crude compound thus obtained was purified by precipitation in a large excess of cold $\mathrm{MeOH}$ from a $\mathrm{CHCl}_{3}$ solution, to afford the desired polymer as a yellow solid (89 $\mathrm{mg}$, $53 \%)$.

IR (ATR) $v_{\max }\left(\mathrm{cm}^{-1}\right): 2924,2853,1466,1048,790 ;{ }^{1} \mathrm{H}$ NMR $\left(300 \mathrm{MHz}, \mathrm{CDCl}_{3}\right): \delta$ 0.71-0.83 (m, 8H), 0.94-1.21 (m, 14H), 1.89-2.15 (m, 4H), $7.30(\mathrm{~s}, 2 \mathrm{H}), 7.48-7.63(\mathrm{~m}, 4 \mathrm{H}), 7.70(\mathrm{~d}, 2 \mathrm{H}, J=7.8 \mathrm{~Hz})$; $\lambda_{\max }$ : $426,450 \mathrm{~nm}$.

2,7-Diformyl-9-(tridecan-7-yl)-9H-carbazole (4). Following a slightly modified literature procedure, ${ }^{37}$ a stirred solution of $3(5.07 \mathrm{~g}, 10 \mathrm{mmol})$ in THF $(50 \mathrm{~mL})$ was cooled to $-78^{\circ} \mathrm{C}$ and a $1.85 \mathrm{M}$ solution of $n$-BuLi in hexanes $(11.4 \mathrm{~mL}, 21 \mathrm{mmol})$ was added and stirred at this temperature for $1 \mathrm{~h}$. Then DMF (2.3 $\mathrm{mL}, 30 \mathrm{mmol})$ in THF $(10 \mathrm{~mL})$ was added dropwise and the reaction mixture was allowed to warm to room temperature and stirred for $1 \mathrm{~h}$. The reaction mixture was quenched with aq. $\mathrm{NH}_{4} \mathrm{Cl}$ and extracted with EtOAc ( 2 x $50 \mathrm{~mL})$. The organic layer was dried over anhydrous $\mathrm{Na}_{2} \mathrm{SO}_{4}$, and solvents evaporated to give a crude mixture, which was purified by column chromatography (silica gel, EtOAc/PET 1:9) to afford 4 as a yellow solid $(3.26 \mathrm{~g}, 81 \%)$.

$\mathrm{Mp}=88-90^{\circ} \mathrm{C}$; IR (ATR) $v_{\max }\left(\mathrm{cm}^{-1}\right): 2917,2850,1676,1227 ;{ }^{1} \mathrm{H}$ NMR $\left(300 \mathrm{MHz}, \mathrm{CDCl}_{3}\right): \delta 0.76(\mathrm{t}$, $6 \mathrm{H}, J=6.6 \mathrm{~Hz}), 0.89-0.92(\mathrm{~m}, 2 \mathrm{H}), 1.04-1.34(\mathrm{~m}, 14 \mathrm{H}), 1.95-2.12(\mathrm{~m}, 2 \mathrm{H}), 2.24-2.42(\mathrm{~m}, 2 \mathrm{H}), 4.72$ (septet, $1 \mathrm{H}, J=5.1 \mathrm{~Hz}), 7.80(\mathrm{~d}, 2 \mathrm{H}, J=7.8 \mathrm{~Hz}), 8.03(\mathrm{~s}, 1 \mathrm{H}), 8.16(\mathrm{~s}, 1 \mathrm{H}), 8.23-8.37(\mathrm{~m}, 2 \mathrm{H})$; ${ }^{13} \mathrm{C} \mathrm{NMR}$ $\left(75 \mathrm{MHz}, \mathrm{CDCl}_{3}\right): \delta 13.88,22.38,26.73,28.90,31.44,33.75,57.37,110.48,113.14,121.08,121.87$, 126.40, 135.21, 143.24, 192.42; HRMS: Calcd. for $\mathrm{C}_{27} \mathrm{H}_{35} \mathrm{NO}_{2}[\mathrm{M}]^{+\cdot}$ 405.26678, found 405.26691.

2,7-Bis(mercaptomethyl)-9-(tridecan-7-yl)-9H-carbazole (C-SH). To a stirred solution of 4 (3.24 g, $8.0 \mathrm{mmol})$ in a 3:1 THF/MeOH mixture $(60 \mathrm{~mL}), \mathrm{NaBH}_{4}(2.43 \mathrm{~g}, 64 \mathrm{mmol})$ was added portion wise at 0 ${ }^{\circ} \mathrm{C}$ and the reaction mixture was allowed to warm to room temperature for $4 \mathrm{~h}$. The reaction was quenched with aqueous $\mathrm{NH}_{4} \mathrm{Cl}$ solution $(100 \mathrm{~mL})$, extracted with EtOAc $(2 \times 100 \mathrm{~mL})$ and the organic layer was dried over anhydrous $\mathrm{Na}_{2} \mathrm{SO}_{4}$. The solvent was then evaporated to afford the desired compound as a pale viscous liquid and used without further purification in the next step. To a stirred solution of the crude compound $(2.96 \mathrm{~g}, 7.24 \mathrm{mmol})$ in benzene $(30 \mathrm{~mL}), \mathrm{PBr}_{3}(1.0 \mathrm{~mL}, 21.8 \mathrm{mmol})$ was slowly added at room temperature, then the reaction mixture was heated to $45^{\circ} \mathrm{C}$ for $6 \mathrm{~h}$. The reaction was quenched with water $(25 \mathrm{~mL})$ and extracted with $\mathrm{CH}_{2} \mathrm{Cl}_{2}(2 \times 50 \mathrm{~mL})$. The organic layer was dried over anhydrous $\mathrm{Na}_{2} \mathrm{SO}_{4}$ and the solvent evaporated. The oily residue, 2,7-bis(bromomethyl)-9-(tridecan-7-yl)-9H-carbazole 5 was used in the next step without purification, since the compound was unstable under ambient condition. To a stirred solution of 5 (3.5 g, $6.5 \mathrm{mmol})$ in EtOH $(30 \mathrm{~mL})$ thiourea $(1.5 \mathrm{~g}, 19.5 \mathrm{mmol})$ was added and the reaction mixture heated to reflux for $8 \mathrm{~h}$. Then, the solvent was evaporated under vacuum, the solid obtained was hydrolyzed with $50 \%$ aqueous sodium hydroxide and extracted with EtOAc $(2 \times 50 \mathrm{~mL})$. The organic layer was dried over anhydrous $\mathrm{Na}_{2} \mathrm{SO}_{4}$, and solvents evaporated to give a crude mixture, which was purified by flash column chromatography (silica, $\mathrm{CH}_{2} \mathrm{Cl}_{2} / \mathrm{PET} 3: 7$ ) to afford $\mathbf{C - S H}$ as a colorless liquid $(1.56 \mathrm{~g}, 55 \%)$. The overall yield for the three steps is $47 \%$.

IR (ATR) $v_{\max }\left(\mathrm{cm}^{-1}\right): 2923,2853,2561,1457,1435 ;{ }^{1} \mathrm{H}$ NMR $\left(300 \mathrm{MHz}, \mathrm{CDCl}_{3}\right): \delta 0.78(\mathrm{t}, 6 \mathrm{H}, J=6.6$ $\mathrm{Hz}), 0.91-1.31(\mathrm{~m}, 16 \mathrm{H}), 1.84(\mathrm{t}, 2 \mathrm{H}, J=7.5 \mathrm{~Hz}), 1.87-1.98(\mathrm{~m}, 2 \mathrm{H}), 2.18-2.35(\mathrm{~m}, 2 \mathrm{H}), 3.94(\mathrm{~d}, 4 \mathrm{H}, J$ $=7.5 \mathrm{~Hz}), 4.53($ septet, $1 \mathrm{H}, J=5.1 \mathrm{~Hz}), 7.16(\mathrm{~d}, 2 \mathrm{H}, J=7.8 \mathrm{~Hz}), 7.34(\mathrm{~s}, 1 \mathrm{H}), 7.50(\mathrm{~s}, 1 \mathrm{H}), 7.91-8.06$ $(\mathrm{m}, 2 \mathrm{H}) ;{ }^{13} \mathrm{C} \mathrm{NMR}\left(75 \mathrm{MHz}, \mathrm{CDCl}_{3}\right): \delta 14.05,22.58,26.77,29.09,30.02,31.60,33.70,56.35,108.25$, 
110.95, 119.00, 120.21, 120.44, 121.36, 138.21, 138.68; HRMS: Calcd. for $\mathrm{C}_{27} \mathrm{H}_{39} \mathrm{NS}_{2}[\mathrm{M}]^{+} \cdot 441.25239$, found 441.25219 .

Synthesis of PFC-S. In a sealed tube, a solution of F-Br $(0.52 \mathrm{~g}, 1 \mathrm{mmol})$ and C-SH $(0.44 \mathrm{~g}, 1 \mathrm{mmol})$ in a 1:1 THF/MeOH mixture $(10 \mathrm{~mL})$ was treated with powdered $\mathrm{KOH}(0.17 \mathrm{~g}, 3 \mathrm{mmol})$ and the reaction mixture was heated to $100{ }^{\circ} \mathrm{C}$ for $14 \mathrm{~h}$. Then, the reaction mixture was cooled to room temperature and the solvent evaporated under vacuum. The crude reaction mixture was washed with $\mathrm{H}_{2} \mathrm{O}$ and $\mathrm{MeOH}$ and the solid filtered. The latter was then dissolved in $\mathrm{CHCl}_{3}(5 \mathrm{~mL})$ and purified by precipitation using $\mathrm{MeOH}(100 \mathrm{~mL})$ to provide the desired compound (PFCS) as a pale yellow solid $(0.62 \mathrm{~g}, 83 \%)$.

IR (ATR) $v_{\max }\left(\mathrm{cm}^{-1}\right): 2922,2849,2354,1599,1440 ;{ }^{1} \mathrm{H}$ NMR $\left(400 \mathrm{MHz}, \mathrm{CDCl}_{3}\right): \delta 0.57-0.80(\mathrm{~m}, 16 \mathrm{H})$, 0.92-1.32 (m, 28H), 1.88-2.08 (m, 6H), 2.25-2.44 (m, 2H), 3.71 (s, 4H), 3.80 (s, 4H), 4.52-4.67 (m, 1H), 7.07-7.16 (m, 2H), 7.21-7.32 (m, 4H), $7.40(\mathrm{~s}, 1 \mathrm{H}), 7.57(\mathrm{~s}, 1 \mathrm{H}), 7.63(\mathrm{~d}, 2 \mathrm{H}, J=7.8 \mathrm{~Hz}),(\mathrm{t}, 2 \mathrm{H}, J=8.7$ $\mathrm{Hz}) ;{ }^{13} \mathrm{C} \mathrm{NMR}\left(100 \mathrm{MHz}, \mathrm{CDCl}_{3}\right): \delta 13.96,22.52,23.82,26.85,29.14,29.74,31.54,31.60,33.83,35.84$, 36.24 , 40.48, 54.96, 56.39, 109.11, 111.78, 119.50, 119.83, 120.08, 121.36, 122.73, 123.49, 127.89, $135.18,135.58,136.97,139.13,139.87,142.55,151.04 ; \lambda_{\max }: 245,276,317 \mathrm{~nm}$.

Synthesis of PFC-SO: A stirred solution of PFC-S $(0.54 \mathrm{~g}, 0.73 \mathrm{mmol})$ in $\mathrm{CHCl}_{3}(15 \mathrm{~mL})$ was treated with $m$-CPBA $(0.63 \mathrm{~g}, 3.6 \mathrm{mmol})$ and the reaction mixture was stirred at room temperature for $8 \mathrm{~h}$. Then, the reaction mixture was filtered and washed with $\mathrm{CHCl}_{3}$. The filtrate was washed with saturated aqueous $\mathrm{NaHCO}_{3}(2 \times 25 \mathrm{~mL})$, brine and water respectively. The organic solvent was evaporated and the crude material thus obtained was purified by precipitation in a large excess of cold $\mathrm{MeOH}$ from a $\mathrm{CHCl}_{3}$ solution, to afford the desired polymer as a dark-green solid $(0.43 \mathrm{~g}, 76 \%)$.

IR (ATR) $v_{\max }\left(\mathrm{cm}^{-1}\right): 2930,2823,1480,1308,1110 ;{ }^{1} \mathrm{H}$ NMR (400 MHz, $\left.\mathrm{CDCl}_{3}\right): \delta 0.58-0.83(\mathrm{~m}, 16 \mathrm{H})$, 0.92-1.29 (m, 28H), 1.88-2.14 (m, 6H), 2.22-2.43 (m, 2H), $4.21(\mathrm{~s}, 4 \mathrm{H}), 4.33(\mathrm{~s}, 4 \mathrm{H}), 4.51-4.71(\mathrm{~m}, 1 \mathrm{H})$, $7.15(\mathrm{~d}, 2 \mathrm{H}, J=8.2 \mathrm{~Hz}), 7.30-7.48(\mathrm{~m}, 4 \mathrm{H}), 7.61(\mathrm{~s}, 1 \mathrm{H}), 7.75(\mathrm{~d}, 2 \mathrm{H}, J=7.6 \mathrm{~Hz}), 7.80(\mathrm{~s}, 1 \mathrm{H}), 8.05-$ $8.21(\mathrm{~m}, 2 \mathrm{H}) ;{ }^{13} \mathrm{C} \mathrm{NMR}\left(100 \mathrm{MHz}, \mathrm{CDCl}_{3}\right): \delta 13.91,13.94,22.44,22.47,23.91,26.80,29.01,29.63$, $31.50,31.55,33.74,40.23,111.45,114.03,120.38,120.63,120.84,121.60,122.47,123.83,124.91$, $125.50,126.73,129.89,139.29,141.14,142.69,151.65 ; \lambda_{\max }: 249,259,275,287,317 \mathrm{~nm}$.

Synthesis of PFVCV. In a sealed round bottom flask, a stirred solution of PFC-SO (0.2 g, $0.26 \mathrm{mmol})$ in a 2:1 THF/t-BuOH mixture $(12 \mathrm{~mL})$ was treated with freshly prepared $\mathrm{Al}_{2} \mathrm{O}_{3}-\mathrm{KOH}(0.3 \mathrm{~g})$ at $0^{\circ} \mathrm{C}$, then $\mathrm{CF}_{2} \mathrm{Br}_{2}(1.5 \mathrm{~mL})$ was added at the same temperature. The reaction mixture was stirred at room temperature for $24 \mathrm{~h}$, then filtered through celite and washed with $\mathrm{CH}_{2} \mathrm{Cl}_{2}$. The solvent was evaporated and the crude material purified by precipitation in a large excess of cold $\mathrm{MeOH}$ from a $\mathrm{CHCl}_{3}$ solution, to afford the desired polymer as a yellow solid (32 $\mathrm{mg}, 43 \%$ ).

IR (ATR) $v_{\max }\left(\mathrm{cm}^{-1}\right): 2924,2853,1466,1048,790 ;{ }^{1} \mathrm{H} \mathrm{NMR}\left(400 \mathrm{MHz}, \mathrm{CDCl}_{3}\right): \delta$ 0.64-0.78 (m, $\left.16 \mathrm{H}\right)$, 0.93-1.16 (m, 28H), 1.86-2.06 (m, 6H), 2.23-2.39 (m, 2H), 4.52-4.62 (m, 1H), 7.22-7.32 (m, 3H), 7.40$7.54(\mathrm{~m}, 6 \mathrm{H}), 7.57-7.67(\mathrm{~m}, 3 \mathrm{H}), 7.94-8.06(\mathrm{~m}, 2 \mathrm{H}) ; \lambda_{\max }: 265,427,452 \mathrm{~nm}$. 


\section{RESULTS AND DISCUSSION}

Synthesis and characterization of symmetrical poly(arylene vinylene)s. For our initial studies, we have selected specific monomers, namely, 2,7-bis(bromomethyl)-9,9'-dihexyl-9H-fluorene (F-Br) and 2,7-bis(mercaptomethyl)-9,9'-dihexyl-9H-fluorene (F-SH) (Scheme 1). The general synthetic strategy to symmetrical PPV's following Route A is outlined in Figure 1. 9,9-Dihexylfluorene has been widely employed as a building block for the synthesis of electroluminescent polymers. ${ }^{38-40}$ Moreover, fluorene-based polymers exhibit excellent solubility, good charge carrier mobility, and high solid state photoluminescence (PL) quantum yield. ${ }^{41}$ Reduction of fluorene-dicarbaldehyde ${ }^{34}$ (1) with $\mathrm{NaBH}_{4}$ in THF/MeOH ${ }^{42}$ afforded the 2,7-bis(hydroxymethyl)-9,9'-dihexyl-9H-fluorene (2) in $80 \%$ yield. Treatment of 2 with $\mathrm{PBr}_{3}$ in benzene ${ }^{35}$ at $45^{\circ} \mathrm{C}$ gave the desired 2,7-bis(bromomethyl)-9,9'-dihexyl-9Hfluorene monomer (F-Br) in 59\% yield. Subsequent treatment of monomer F-Br with thiourea in refluxing $\mathrm{EtOH}$ for $4 \mathrm{~h}$ followed by basic hydrolysis provided the desired monomer, F-SH (Scheme 1). ${ }^{36}$

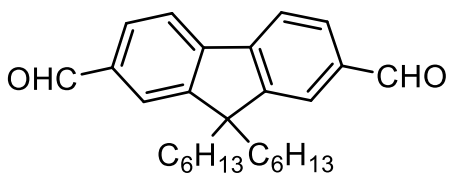

1

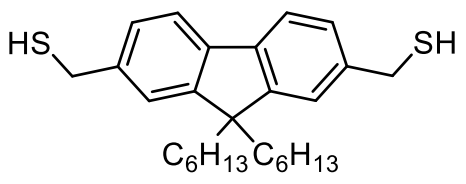

F-SH

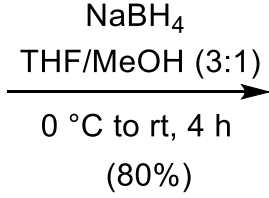

$(80 \%)$

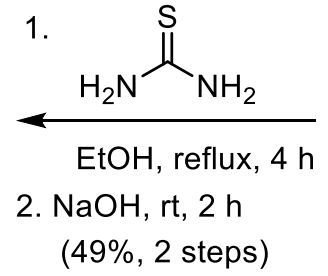

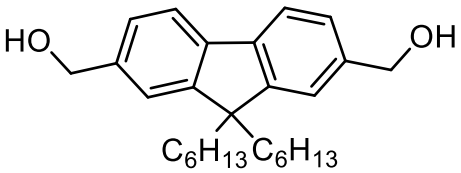

2

$(59 \%) \mid \begin{gathered}\mathrm{PBr}_{3}, \text { benzene } \\ 45^{\circ} \mathrm{C}, 6 \mathrm{~h}\end{gathered}$

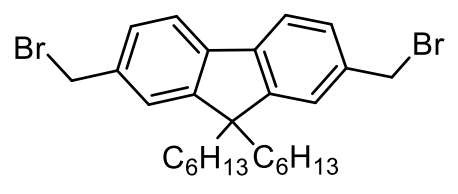

$\mathbf{F}-\mathrm{Br}$

Scheme 1. Synthesis of monomers 2,7-Bis(bromomethyl)-9,9'-dihexyl-9H-fluorene (F-Br) and 2,7Bis(mercaptomethyl)-9,9'-dihexyl-9H-fluorene (F-SH).

The general protocol for the preparation of poly(fluorene vinylene) (PFV) is illustrated in Scheme 2. After screening various conditions for the step-growth polymerization of stoichiometric amounts of FBr and F-SH (see ESI, Tables S1-4), soluble polymers of rather high apparent molecular weight were obtained in presence of 3 eq. of powdered $\mathrm{KOH}$ in THF/MeOH (1:1) at $100{ }^{\circ} \mathrm{C}$ for $14 \mathrm{~h}$. These conditions led to poly(fluorene-sulfide)s (PF-S) in 78\% final yield. Strong, non-nucleophilic 1,1,3,3tetramethylguanidine (TMG) afforded higher molecular weights and narrower dispersities (see ESI). Due to their lower molecular weight, however, polymers obtained from $\mathrm{KOH}$ also proved more soluble. Initial studies on the oxidation of PF-S using oxone ${ }^{\circledR}$ as the oxidizing agent in $\mathrm{MeOH} / \mathrm{H}_{2} \mathrm{O}$ were unsuccessful, resulting in a mixture of sulfoxide and sulfone products. In contrast, treatment of 1 eq. of PF-S with 5 eq. of $m$-CPBA in $\mathrm{CHCl}_{3}$ at room temperature for $8 \mathrm{~h}$ afforded the polyfluorene-sulfone (PF-SO) in 63 $\%$ yield. The latter polymer was finally subjected to the Ramberg-Bäcklund reaction using Chan's modified procedure $\left(\mathrm{CF}_{2} \mathrm{Br}_{2}, \mathrm{Al}_{2} \mathrm{O}_{3}-\mathrm{KOH}, t-\mathrm{BuOH}\right) .{ }^{43}$ The reaction was however sluggish under these conditions, very likely because of the low solubility of PF-SO in $t$-BuOH. We noted that a mixture of 
THF and $t$ - $\mathrm{BuOH}$ (1:1) was more suitable for this reaction. Treatment of PF-SO with an excess of $\mathrm{CF}_{2} \mathrm{Br}_{2}$ and freshly prepared $\mathrm{Al}_{2} \mathrm{O}_{3}-\mathrm{KOH}$ in $\mathrm{THF} / t-\mathrm{BuOH}(1: 1)$, at room temperature for $24 \mathrm{~h}$, thus gave polymer PFV in 53\% yield. The three polymers, PF-S, PF-SO and PFV were purified by precipitation using $\mathrm{CHCl}_{3}$ and $\mathrm{MeOH}$ at room temperature.

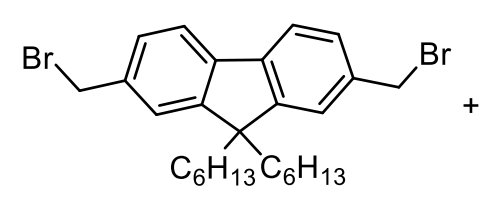

$\mathrm{F}-\mathrm{Br}$

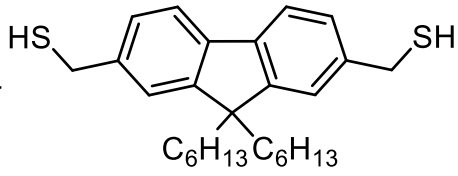

F-SH

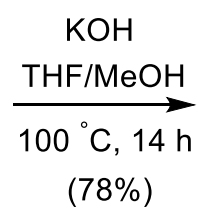

$(78 \%)$

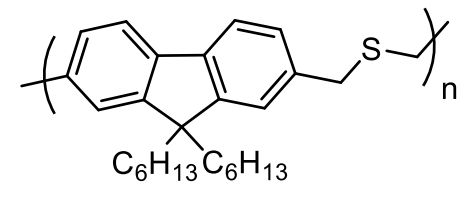

PF-S

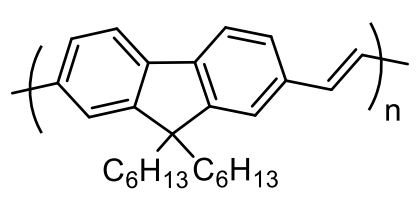

PFV

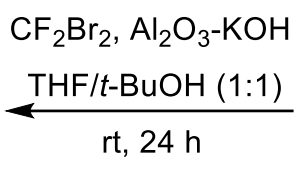

$(53 \%)$

Scheme 2. Synthesis of poly(fluorene vinylene) (PFV) via a three-step procedure involving stepgrowth polymerization, oxidation and Ramberg-Bäcklund reaction.

Table 1. Size exclusion Chromatography (SEC) analysis of polymers in THF at $25^{\circ} \mathrm{C}$ using PS standards for calibration

\begin{tabular}{ccccc} 
entry & polymer & $\begin{array}{c}\bar{M}_{\mathrm{n}}^{(\mathrm{a})} \\
(\mathrm{g} / \mathrm{mol})\end{array}$ & $\begin{array}{c}\bar{M}_{\mathrm{w}}^{(\mathrm{a})} \\
(\mathrm{g} / \mathrm{mol})\end{array}$ & $\bigoplus^{(\mathrm{a})}$ \\
\hline 1 & PF-S & 7,500 & 14,300 & 1.90 \\
2 & PF-SO & 15,000 & 32,000 & 2.10 \\
3 & PFV & 7,600 & 13,200 & 1.70 \\
4 & PFC-S & 40,700 & 82,300 & 2.02 \\
5 & PFC-SO & 30,400 & 61,200 & 2.01 \\
6 & PFVCV & 5,500 & 11,400 & 2.05
\end{tabular}

(a) Number- and weight-average molar mass (in g.mol ${ }^{-1}$ ) and dispersity determined by size exclusion chromatography in THF (PS calibration).

Characterization of the monomers and related polymers (PF-S, PF-SO, PFV) through IR and ${ }^{1} \mathrm{H}$ NMR spectroscopies; revealed the expected structures with high purity (Figure 2). The overlay of IR spectra of the different polymers is shown in Figure S1 (ESI). Comparison between IR spectra of PF-S and PF-SO showed additional absorption bands at $1319,1100 \mathrm{~cm}^{-1}$, corresponding to the $\mathrm{S}=\mathrm{O}$ group. During post-functionalization of PF-SO into PFV, disappearance of the band at $1319 \mathrm{~cm}^{-1}$ and a new absorption band at $860 \mathrm{~cm}^{-1}$ due to the olefinic moiety was observed, confirming the complete 
transformation of the sulfone group. ${ }^{1} \mathrm{H}$ NMR spectra revealed the presence of methylene protons for monomers F-Br and F-SH appearing at $\delta 4.59$ (s) and 3.82 (d) ppm, respectively. These signals vanished in the spectrum of PF-S, where a single peak at $\delta 3.68 \mathrm{ppm}$ (Figure 2) was noted. Upon oxidation, the methylene protons of PF-SO were shifted downfield to $\delta 4.20 \mathrm{ppm}$. Importantly, no signal around $\delta 3.90$ ppm, resulting from a partial oxidation of the sulfide into the sulfoxide was detected. ${ }^{44}$ After treating the PF-SO under modified Ramberg-Bäcklund reaction conditions, ${ }^{1} \mathrm{H}$ NMR of PFV revealed a $(E)$ stereoselectivity for the double bonds, a result consistent with observations made for model dibenzylic sulfones reported earlier, ${ }^{43,45}$ and that is in good agreement with spectroscopic data reported by Nomura et al. concerning PFV synthesis by ADMET. ${ }^{32,33}$ It is also worth mentioning that we did not observe any residual benzylic protons at $\delta 4.20 \mathrm{ppm}$, attesting to the complete conversion of dibenzylic sulfones into olefinic moieties, and to the formation of fully $\pi$-conjugated polymers. Average molecular weights were evaluated by size exclusion chromatography (SEC) in THF using polystyrene standards. Results are summarized in Table 1 and SEC traces of PFV, PF-S and PF-SO are shown in Figure 3. The fluorenebased copolymer, PF-S, is characterized by a moderate molecular weight for the parent compounds (Table 1, entry 1), increasing after sulfonation (Table 1, entry 2). The final polymer, PFV, has a similar molecular weight than its precursor PF-S (Table 1, entry 3). After post-chemical modification forming the sulfone and the $\pi$-conjugated polymers, $\mathrm{M}_{\mathrm{n}}$ and $\mathrm{M}_{\mathrm{w}}$ values changed significantly, most likely owing to the variation of solubility of the different polymers. Finally, the high thermal stability of the different polymers (PF-S, PF-SO, PFV) was established by TGA with a loss less than 10\% upon heating up to $400{ }^{\circ} \mathrm{C}$ (see Figure S6, ESI).

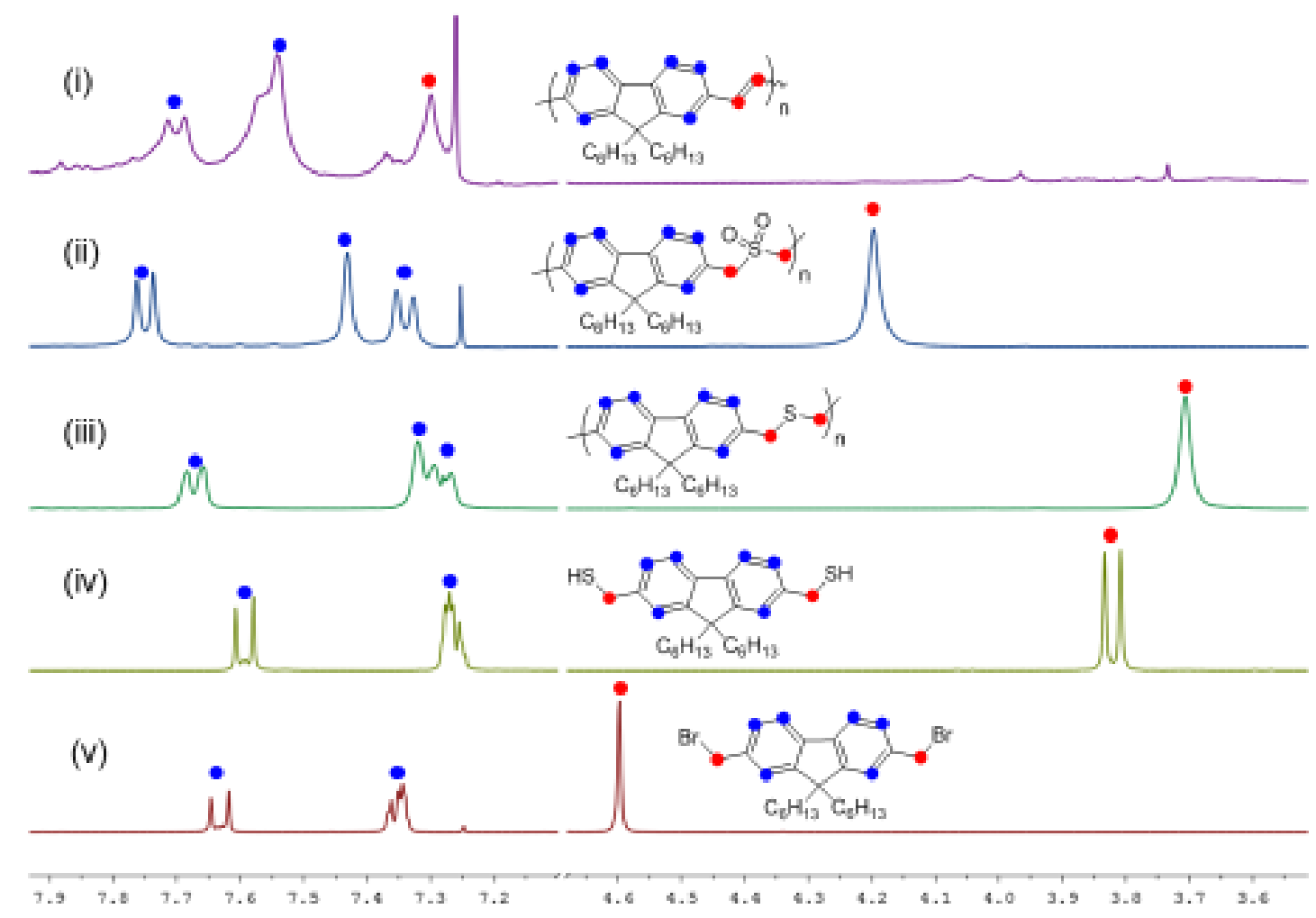

Figure 2. ${ }^{1} \mathrm{H}$ NMR spectra of (i) PFV; (ii) PF-SO 2 ; (iii) PF-S; (iv) F-SH; (v) F-Br in $\mathrm{CDCl}_{3}$ (400 MHz); $n$-hexyl peaks are omitted for clarity. 


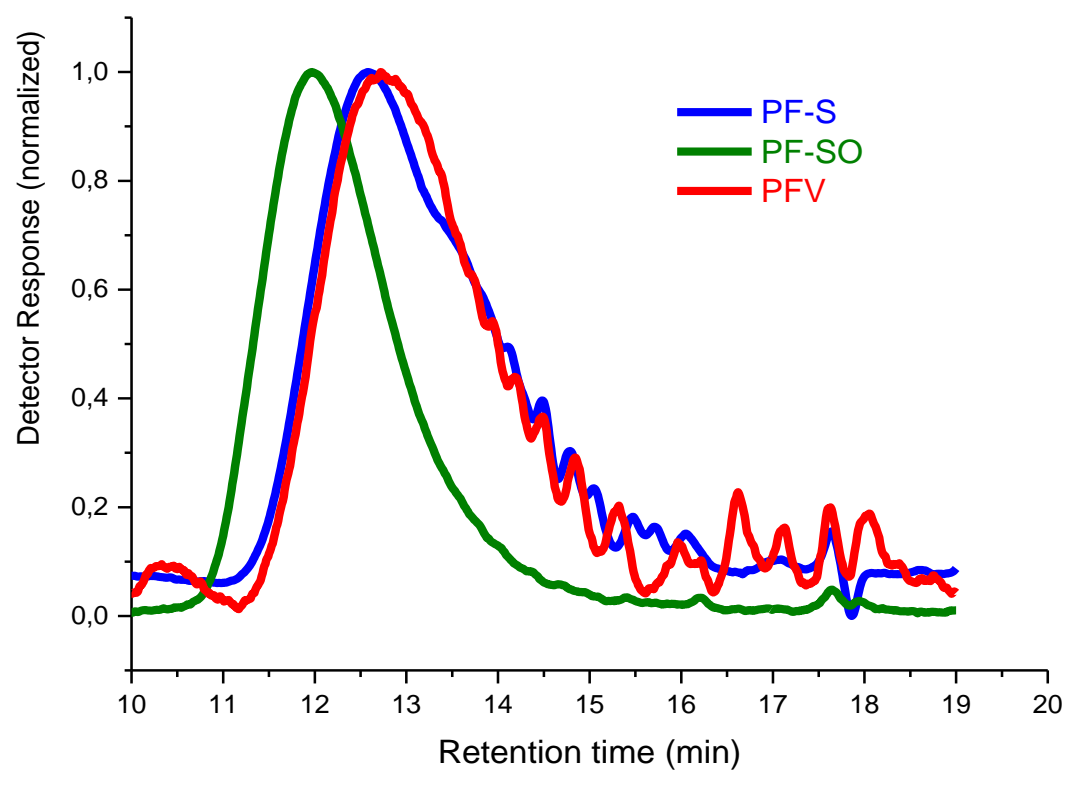

Figure 3. SEC traces in THF (PS standards; RI Detector) of PFV, PF-SO and PF-S.

\section{Synthesis of poly(fluorene-sulfone)s (PF-SO) via the Rongalite ${ }^{\circledR}$ route (see Scheme 3).}

With a view at developing a simpler and inexpensive protocol for the synthesis of polysulfone-type precursors of the Ramberg-Bäcklund reaction, we envisioned that commercially available rongalite ${ }^{\circledR}, 46$ i.e. sodium hydroxymethanesulfinate, could serve as a source of sulfoxylate dianion $\left(\mathrm{SO}_{2}{ }^{2-}\right)$. Rongalite ${ }^{\circledR}$ is inexpensive and is used as a less oxygen-sensitive bleaching agent than sodium dithionite $\left(\mathrm{Na}_{2} \mathrm{~S}_{2} \mathrm{O}_{4}\right)$, for the synthesis of symmetrical sulfones. Best results were obtained when treated 1 eq. of fluorene- $\mathrm{Br}$ (F-Br) with rongalite ${ }^{\circledR}$ (5 eq.) in the presence of $\mathrm{K}_{2} \mathrm{CO}_{3}$ (5 eq.) and tetra- $n$-butylammonium bromide (TBAB) (0.5 eq.) as a phase-transfer catalyst in DMF at room temperature for 3 days (Scheme 3). This gave the desired polyfluorene-sulfone (PF-SO) with $\bar{M}_{\mathrm{n}}=2700 \mathrm{~g} / \mathrm{mol}$ and $Ð=1.7$. Despite a modest isolated yield of 37\%, and low molecular weight, this method opens up an easy entry to PF-SO, and its application affords an access to symmetrical PPV-like materials in only two-step from readily available benzylic bromides.

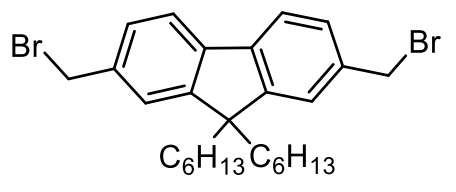

$\mathrm{F}-\mathrm{Br}$

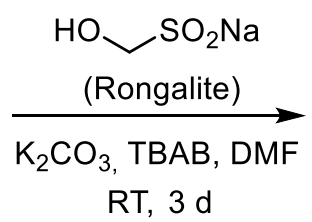

$(37 \%)$

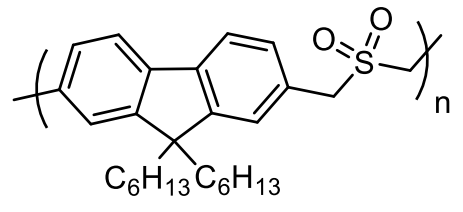

PF-SO

Scheme 3. An access to PF-SO using the rongalite ${ }^{\circledR}$ route. 
Synthesis of unsymmetrical poly(arylene vinylene)s. Based on the above findings, we extended our strategy to the synthesis of unsymmetrical poly(arylene vinylene)s ( $\mathrm{PAr}^{1,2} \mathrm{~V}^{\text {'s; }}$ route B, Figure 1). A dithiol-functionalized carbazole derivative (C-SH) was thus selected as a co-monomer, the latter being synthesized as shown in Scheme $4 .{ }^{37}$ Compound 5 being not stable at room temperature, the crude compound was used in the next step without further purification, leading to the desired C-SH in 55\% yield, after treatment with thiourea and hydrolysis under basic conditions.
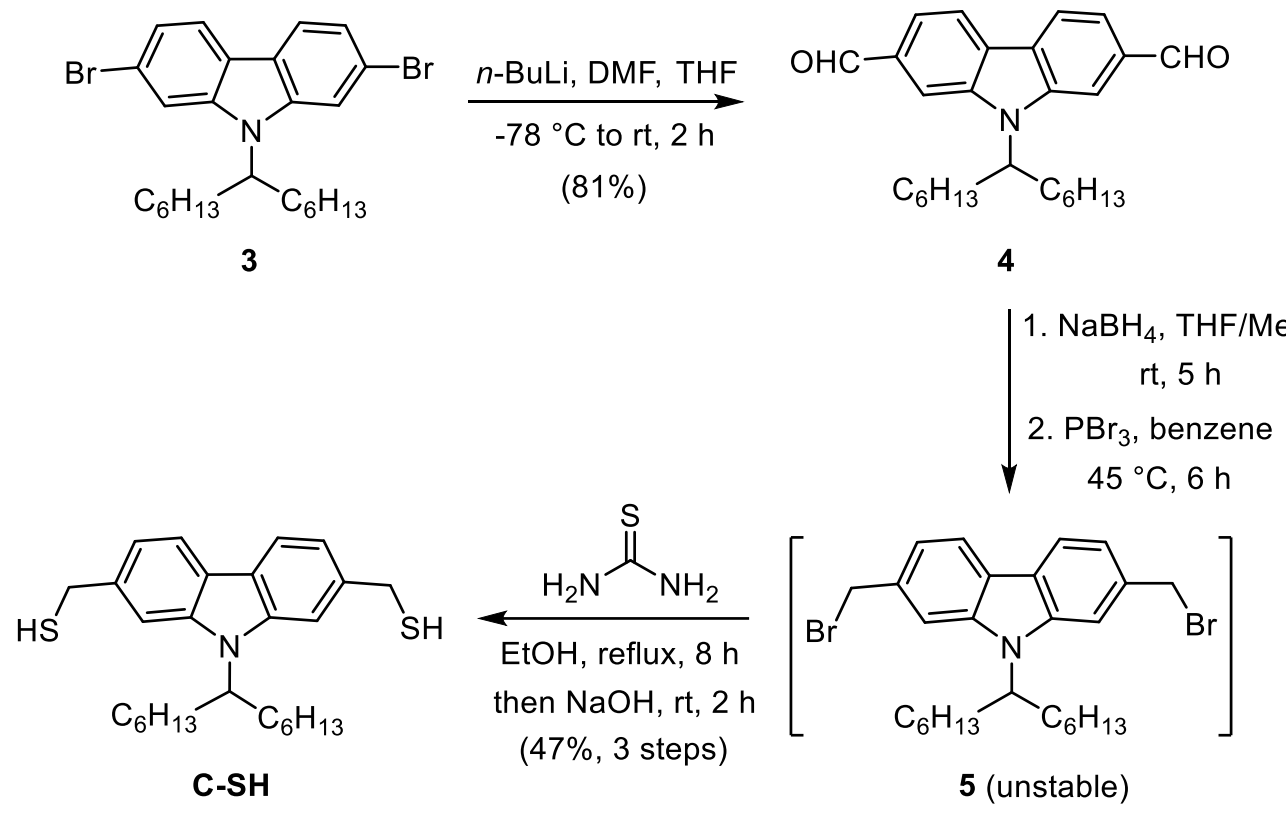

Scheme 4. Synthesis of carbazole monomer C-SH.

To validate our strategy for the synthesis of alternated poly(arylene vinylene)s (Route B, Figure 1), 1 eq. of F-Br was treated with 1 eq. of $\mathbf{C - S H}$ in the presence of 3 eq. of powdered $\mathrm{KOH}$ in $\mathrm{THF} / \mathrm{MeOH}$ at $100{ }^{\circ} \mathrm{C}$ for $14 \mathrm{~h}$ (Scheme 5). This gave a polysulfide, PFC-S, in 83\% yield after purification. Oxidation of PFC-S with 5 eq. of $m$-CPBA in $\mathrm{CHCl}_{3}$ at room temperature for $8 \mathrm{~h}$ provided the corresponding polysulfone (PFC-SO) in 76\% yield. Finally, treatment of PFC-SO under Ramberg-Bäcklund conditions produced the desired poly(fluorene vinylene-co-carbazole vinylene) (PFVCV) in 43\% yield. 


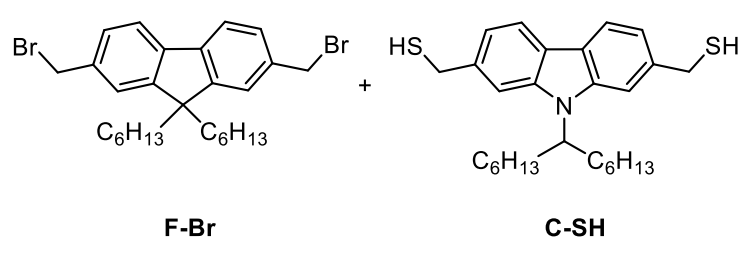

$\underset{(83 \%)}{\stackrel{\mathrm{KOH}, \mathrm{THF} / \mathrm{MeOH}}{100{ }^{\circ} \mathrm{C}, 14 \mathrm{~h}}}$

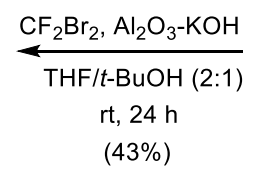

PFVCV
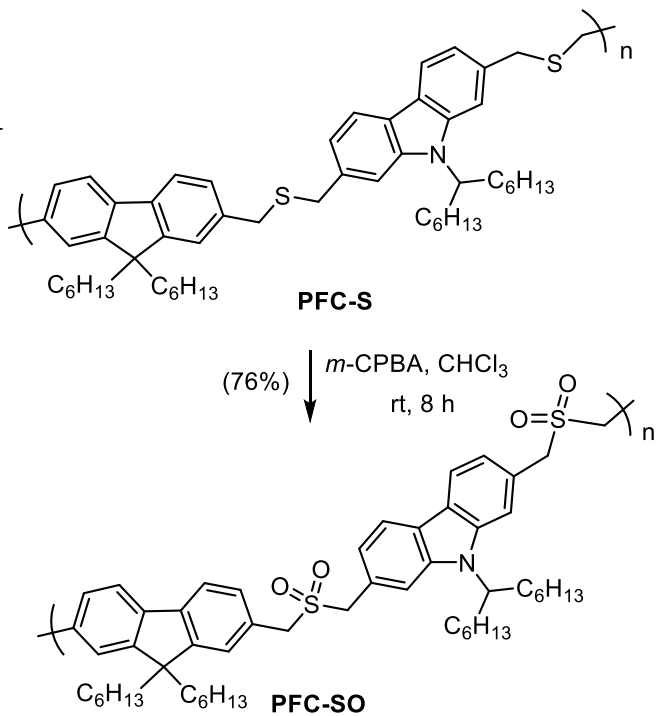

Scheme 5. Synthesis of poly(fluorene vinylene-co-carbazole vinylene) PFVCV.

Monomers and polymers (PFC-S, PFC-SO and PFVCV) were characterized by SEC, IR and ${ }^{1} \mathrm{H}$ NMR spectroscopy. Similar patterns were observed by ${ }^{1} \mathrm{H}$ NMR, as illustrated in Figure 4. Polysulfides PFC$\mathbf{S}$ exhibited high apparent molecular weights (Table 1, entries 4-6). Again, this could be due to an increase of the hydrodynamic volume in THF after sulfonation. Higher molecular weights were achieved for the parent PVCS (Table 1, entry 4), but lower values were noted after the two modification steps forming PFC-SO and PFVCV (Table 1, entries 5-6), respectively (see SEC traces in Figure 5). This could not only be explained by a different solution behavior, but also by possible fractionation during purification by filtration, in agreement with the decrease in dispersity. As above for PFV, high thermal stability of the polymers (PFC-S, PFC-SO and PFVCV) was shown by TGA (see Figure S6, ESI). 


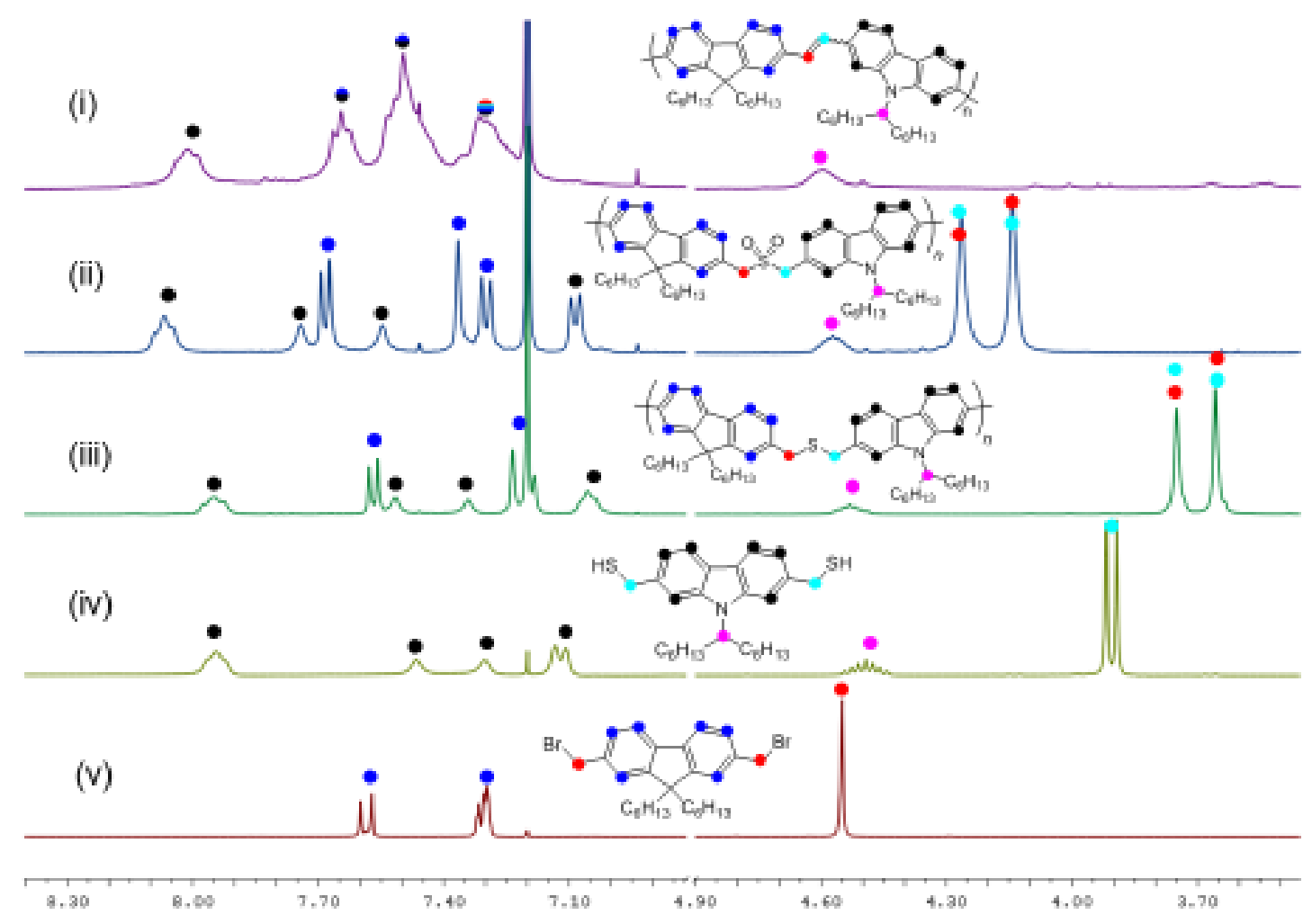

Figure 4. ${ }^{1} \mathrm{H}$ NMR spectra of (i) PFCV; (ii) PFC-SO; (iii) PFC-S; (iv) C-SH; (v) F-Br in $\mathrm{CDCl}_{3}(400$ $\mathrm{MHz})$; The $n$-hexyl peaks are omitted for clarity.

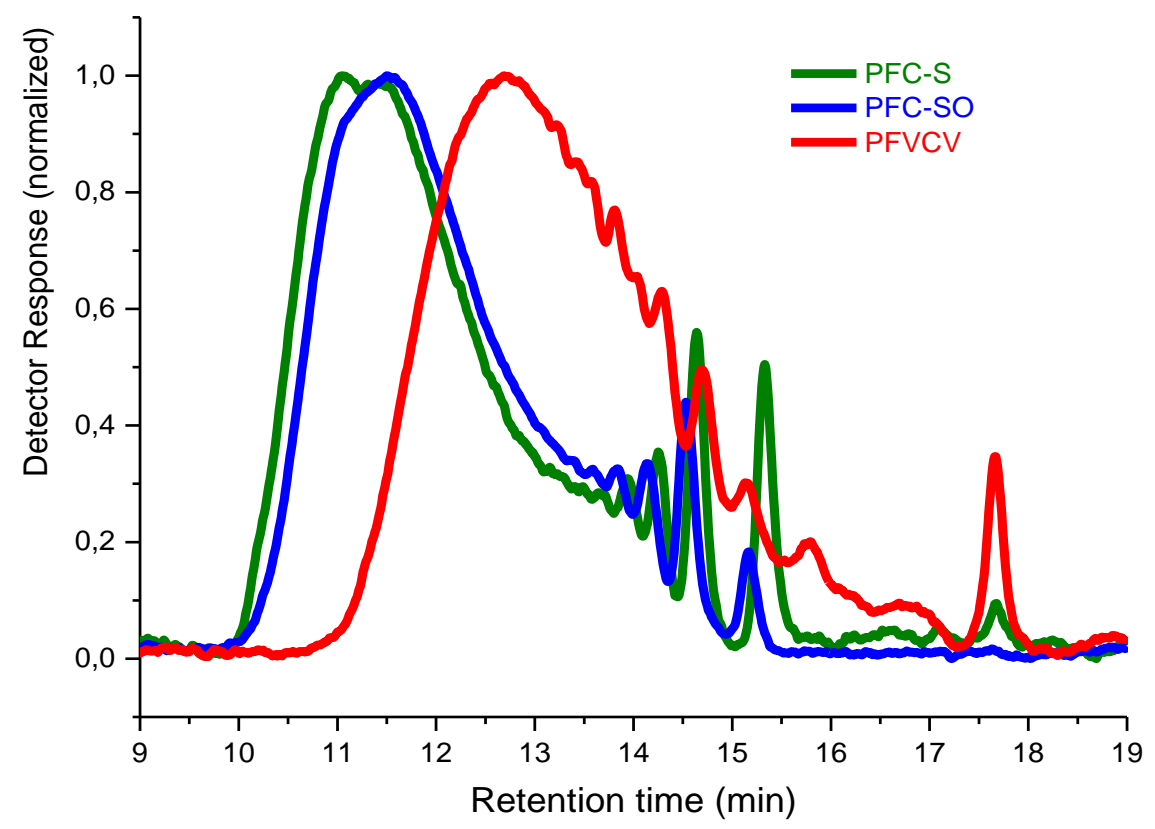

Figure 5. SEC traces in THF of PFVCV, PFC-SO and PFC-S. 
Overall, this three-step reaction sequence to poly(arylene vinylene)s is efficient and stereoselective, although the Ramberg-Bäcklund reaction step gives moderate yields, particularly when steric hindrance around the olefinic moiety is increasing. This limitation is likely inherent to the Ramberg-Bäcklund reaction, which proceeds through an episulfone intermediate resulting from the displacement of the halogen $\alpha^{\prime}$ to the sulfonyl group by an $\alpha$-carbanion (Scheme 6). This process is believed to occur through a semi-W-conformation, the elimination step being rate-limiting. ${ }^{47-48}$ While this conformation is easily attained in small acyclic systems, this might not be the case with polymeric chains, in which strain and folding might retard the elimination and the subsequent $\mathrm{SO}_{2}$ extrusion. This might also explain the long reaction time needed in our polymerization experiments, compared to those noted with molecular compounds, and the low conversion with substrates having substituents on the arenes ortho to the sulfonyl chain (not described here).

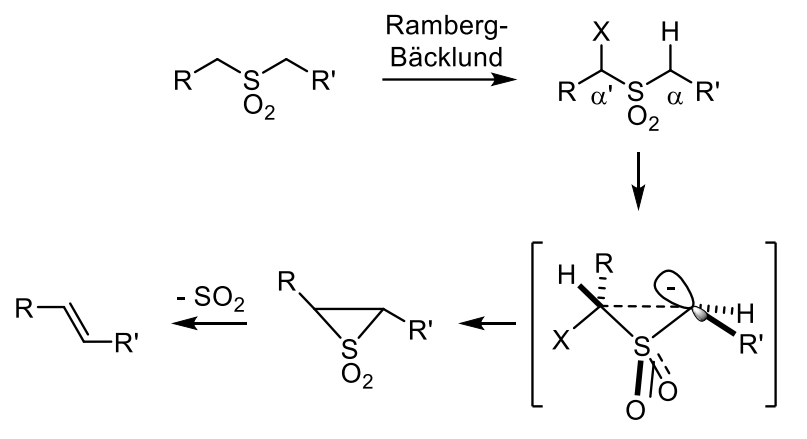

Scheme 6. Conformational requirements in the Ramberg-Bäcklund reaction.

Optical properties. The optical properties of the final (co)polymers were analyzed by UV-Vis absorption and fluorescence spectrophotometry (PFV, PFVCV) both in solution in chloroform and in bulk on solid thin films. UV-Vis in chloroform are shown for PFV (and its precursors PF-S and PF-SO) on Figure 6, and for for PFVCV (and its precursors PFC-S and PFC-SO) on Figure 7. In both cases, a strong red-shift for the two final (co)polymers can be observed. It can be attributed to the extension of the conjugation for PFV and PFVCV, while their precursors are not $\pi$-conjugated. Surprisingly, the two (co)polymers, PFV and PFVCV showed almost the same UV-Vis pattern in chloroform solution (Figures 6 and 7), exhibiting in both cases two absorption maxima around 425 and $455 \mathrm{~nm}$ in solution. These UV data are very similar to those of PFV synthesized by the ADMET method, as reported by Namura et al. ${ }^{33}$ In other words, alternation with carbazole subunits did not affect optical properties of the material. No significant change was eventually noted in the UV-Vis absorption from thin-films of (co)polymers PFV \& PFVCV (See ESI, Figure S5). The absorption bands were slightly red-shifted relative to that of PFV derivatives. ${ }^{49}$ Such small differences can be assigned to the effect of alkyl chains from fluorene repeating units that are shorter in our case, thus favoring $\pi-\pi$ stacking and extension of conjugation length. The optical band gaps $(E g)$ for both polymers, calculated from the onset of the absorption, were approximately $2.6 \mathrm{eV}$. 


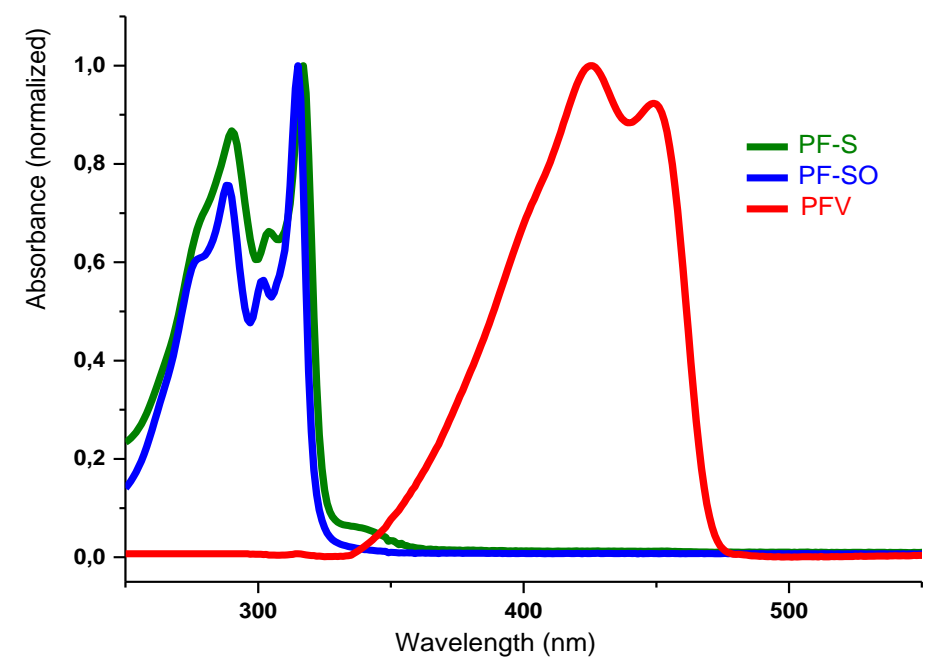

Figure 6. UV-vis absorption of PF-S, PF-SO and PFV

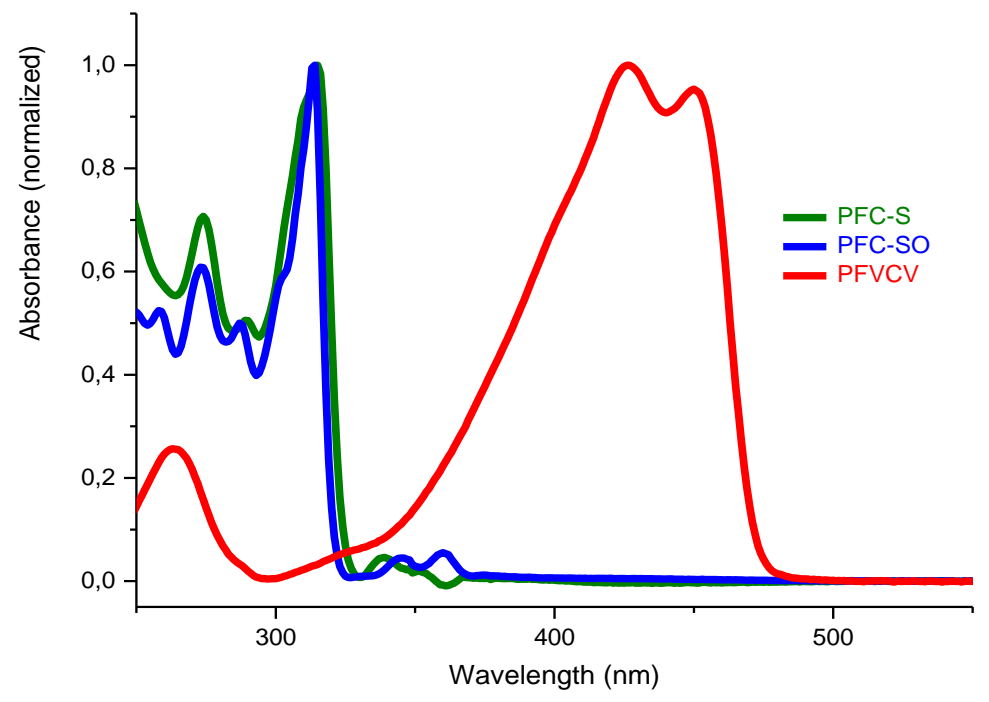

Figure 7. UV-vis absorption of PFC-S, PFC-SO and PFVCV.

Figures 8 and 9 shows the fluorescence spectra recorded with the excitation wavelength corresponding to the two maxima of absorption of the polymers at 425 and $450 \mathrm{~nm}$. In solution, two maxima are observed for both polymers (as well as a slight shoulder) and the corresponding wavelengths are slightly dependent on the wavelength of excitation. For instance, a PFV excitation at $425 \mathrm{~nm}$ (Figure 8(a)) led to a strong emission band at $463 \mathrm{~nm}$, then a shoulder at $494 \mathrm{~nm}$ and a slight shoulder at $534 \mathrm{~nm}$ in excellent agreement with Nomura's emission spectrum recorded at $426 \mathrm{~nm}(465,496$ and $530 \mathrm{~nm}$ respectively). ${ }^{33}$ However, in solid state, broad emission peaks can be observed for both, in almost all the visible region and whatever the wavelength of excitation. In solution, both polymer exhibit two maxima of emission at $475 \mathrm{~nm}$ and $500 \mathrm{~nm}$. When excited at $450 \mathrm{~nm}$ (Figures 8(b) and 9(b)), the second emission 
peak was more prominent than when excitation was performed at $425 \mathrm{~nm}$ (Figures 8(a) and 9(a)). In solid thin films, both polymers (PFV and PFVCV) exhibited a broad emission band, even when they were excited at $425 \mathrm{~nm}$ (Figures 8(c) and 9(c)) or at $450 \mathrm{~nm}$ (Figures 8(b) and 9(b)). However, two main differences can be highlighted between PFV and PFVCV emission spectra in thin film. First, a more prominent emission peak was noted around $512 \mathrm{~nm}$ for PFVCV (Figure 9 (c) and 9 (d)), in agreement with reported data on poly(carbazolyl-2,7-vinylene), which is characteristic of a more blueish emitted light as compared to greenish-blue emitted light from PFV. ${ }^{50}$ Secondly, the emission band was extended up to $700 \mathrm{~nm}$ in the case of PFV, compared to $650 \mathrm{~nm}$ for PFVCV, emphasizing the impact of the carbazolyl vinylene group insertion. This strongest red-shift in solid state for PFV could also be explained by a better organization (e.g. $\pi-\pi$ stacking) comparing to PFVCV. Finally, the quantum yield of the purified PFV material, measured upon excitation at $400 \mathrm{~nm}$ in THF, reached $40.3 \%$ (ESI). Although lower than those found by Nomura et al., ${ }^{33}$ our values are very satisfactory, indicating that the PFV prepared through our method is also free of defects, as further supported by the similar absorption and emission maxima (vide supra).
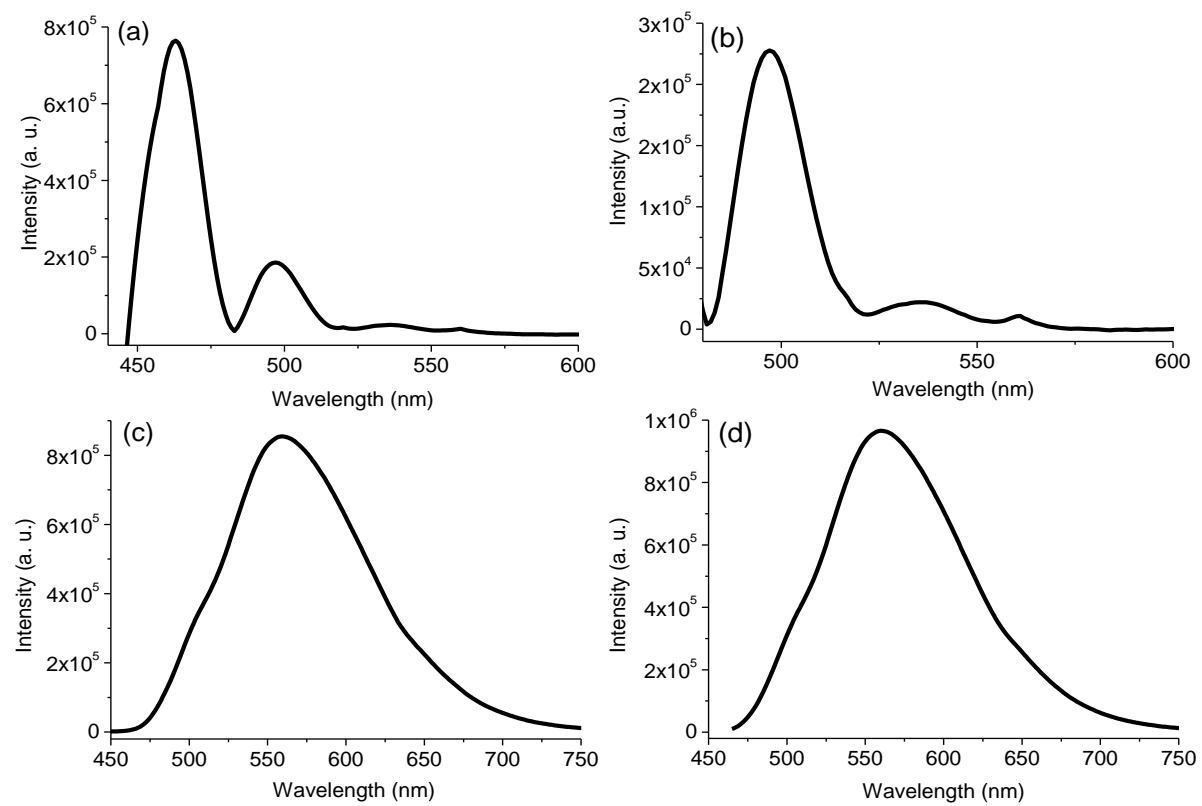

Figure 8. Emission spectra of PFV: (a) excited at $425 \mathrm{~nm}$ in $\mathrm{CHCl}_{3}$; (b) excited at $450 \mathrm{~nm}$ in $\mathrm{CHCl}_{3}$; (c) excited at $420 \mathrm{~nm}$ on thin film; (d) excited at $450 \mathrm{~nm}$ on thin-film. 

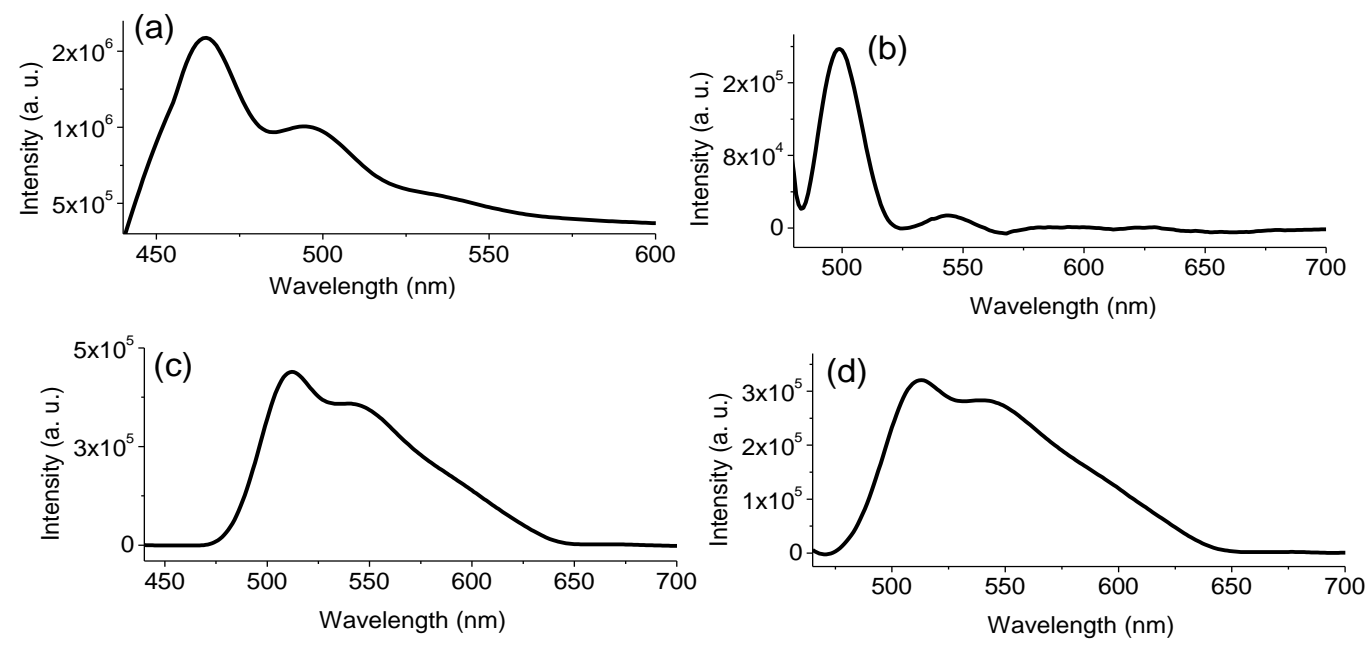

Figure 9. Emission spectra of PFVCV: (a) excited at $425 \mathrm{~nm}$ in $\mathrm{CHCl}_{3}$; (b) excited at $450 \mathrm{~nm}$ in $\mathrm{CHCl}_{3}$; (c) excited at $425 \mathrm{~nm}$ on thin film; (d) excited at $450 \mathrm{~nm}$ on thin-film.

For quenched poly(fluorene vinylene), PFVQ, despite a slight variation of molar masses, there is no significant change in the absorption and emission spectral properties (Figures S3-4, ESI).

Thermal stability. The thermal stability of PFV and its precursors (PF-S, PF-SO) as well as the stability of PFVCV were finally analyzed by TGA (See ESI, Figure S6). The two conjugated polymers PFV and PFVCV are stable until $450{ }^{\circ} \mathrm{C}$. Their precursors (of sulfide- and sulfone-type) are reacting at lower temperatures (between $300{ }^{\circ} \mathrm{C}$ and $350{ }^{\circ} \mathrm{C}$ ) and finally start to decompose at $450{ }^{\circ} \mathrm{C}$.

\section{CONCLUSION}

A novel synthetic strategy involving a sulfone-based precursor step-growth polymerization route followed by post-chemical modification via the Ramberg-Bäcklund reaction provides an easy access to poly(arylene vinylene)-like semiconductors. The sulfone precursors are easily obtained allowing the connection between electronically differentiated arenes. Symmetrical polysulfones may also be elaborated starting from benzylic bromides precursors and rongalite ${ }^{\circledR}$ as a source of sulfoxylate dianion $\left(\mathrm{SO}_{2}{ }^{2-}\right)$. Polysulfones and their polysulfide precursors can be equipped with apolar alkyl chains, thus securing their solubility in organic solvents during polymer elaboration, allowing the final purification of the material through precipitation. Further optimization may be needed, in particular to reduce the environmental impact of the reaction sequence. However, such a methodology used to synthesize copolymers composed of carbazolyl and fluorenyl subunits paves the way for the preparation of a plethora of copolymer structures and/or various architectures. We are for instance currently investigating alternation of electron-rich and electron-poor subunits, along with the integration of such materials free of transition metal sources in optoelectronic devices. 


\section{REFERENCES}

(1) Wang, C.; Dong, H.; Hu, W.; Liu, Y.; Zhu, D., Semiconducting $\pi$-Conjugated Systems in FieldEffect Transistors: A Material Odyssey of Organic Electronics, Chem. Rev. 2012, 112, 2208-2267.

(2) Swager, T. W., 50th Anniversary Perspective: Conducting/Semiconducting Conjugated Polymers. A Personal Perspective on the Past and the Future, Macromolecules 2017, 50, 4867-4886.

(3) Granstrom, M.; Petritsch, K.; Arias, A. C.; Lux, A.; Andersson, M. R.; Friend R. H., Laminated Fabrication of Polymeric Photovoltaic Diodes, Nature 1998, 395, 257-260.

(4) Gunes, S.; Neugebauer, H.; Sariciftci, N. S., Conjugated Polymer-Based Organic Solar Cells, Chem Rev. 2007, 107, 1324-1338.

(5) Grimsdale, A. C.; Leok Chan, K.; Martin, R. E.; Jokisz, P. G.; Holmes, A. B., Synthesis of LightEmitting Conjugated Polymers for Applications in Electroluminescent Devices, Chem. Rev. 2009, 109, 897-1091.

(6) Skotheim, T. A.; Reynolds, J. R., Eds. Handbook of Conducting Polymers, Third ed.: Conjugated Polymers, Theory, Synthesis, Properties, and Characterization; CRC Press LLC: Boca Raton, FL, 2007.

(7) Burroughes, J. H.; Bradley, D. D. C.; Brown, A. R.; Marks, R. N.; Mackay, K.; Friend, R. H.; Burn P. L.; Holmes, A. B., Light-emitting Diodes Based on Conjugated Polymers, Nature 1990, 347 , 539-541.

(8) Morin, J. F.; Drolet, N.; Tao, Y.; Leclerc, M., Syntheses and Characterization of Electroactive and Photoactive 2,7-Carbazolenevinylene-Based Conjugated Oligomers and Polymers, Chem. Mater. 2004, 16, 4619-4626.

(9) Davey, A. P.; Drury, A.; Maier, S.; Byrne, H. J.; Blau, W. J., Synthesis and Optical Properties of Phenylene-vinylene Copolymers, Synth. Met. 1999, 103, 2478-2479.

(10) Anuragudom, P.; Newaz, S. S.; Phanichphant, S.; Lee, T. R., Facile Horner-Emmons Synthesis of Defect-Free Poly(9,9-dialkylfluorenyl-2,7-vinylene), Macromolecules 2006, 39, 3494-3499.

(11) Liu, Q.; Liu, W.; Tian, H.; Xie, Z.; Geng, Y.; Wang, F., Synthesis and Chain-Length Dependent Properties of Monodisperse Oligo(9,9-di-n-octylfluorene-2,7-vinylene)s, Macromolecules 2007, 40, 1851-1857.

(12) Scherf, U.; Müllen, K., Design and Synthesis of Extended $\pi$-Systems: Monomers, Oligomers, Polymers, Synthesis 1992, 23-38.

(13) Meier, H. The Photochemistry of Stilbenoid Compounds and Their Role in Materials Technology Angew. Chem. Int. Ed. 1992, 31, 1399-1540.

(14) Neef, C. J.; Ferraris, J. P., MEH-PPV: Improved Synthetic Procedure and Molecular Weight Control, Macromolecules 2000, 33, 2311-2314.

(15) Wessling, R. A.; Zimmerman, R. G., Polyelectrolytes from Bis-sulfonium Salts, U.S. Patent 3401152, 1968.

(16) Wessling, R. A., The Polymerization of Xylylene Bisdialkylsulfonium Salts, J. Polym. Sci., Polym. Symp. 1985, 72, 55-66.

(17) Dilien, H.; Palmaerts, A.; Lenes, M.; de Boer, B.; Blom, P.; Cleij, T. J.; Lutsen, L.; Vanderzande, D., A Deeper Insight into the Dithiocarbamate Precursor Route: Synthesis of Soluble Poly(thienylene vinylene) Derivatives for Photovoltaic Applications, Macromolecules 2010, 43, 10231-10240. 
(18) Henckens, A.; Colladet, K.; Cleij, T. J.; Lutsen, L.; Gelan, J.; Vanderzande, D., Synthesis of 3,4Diphenyl-Substituted Poly(Thienylene Vinylene), Low-Band-Gap Polymers via the Dithiocarbamate Route, Macromolecules 2005, 38, 19-26.

(19) Zaquen, N.; Lutsen, L.; Vanderzande, D.; Junkers, T., Controlled/Living Polymerization Towards Functional Poly(p-phenylene vinylene) Materials, Polym. Chem. 2016, 7, 1355-1367.

(20) Junkers, T.; Vandenbergh, J.; Adriaensens, P.; Lutsen, L.; Vanderzande, D., Synthesis of Poly(pphenylene vinylene) Materials via the Precursor Routes, Polym. Chem. 2012, 3, 275-285.

(21) Taylor, R. J. K.; Casy, G., The Ramberg-Bäcklund Reaction, Org. React. 2003, 62, 357-475 and references cited therein.

(22) Chow, H. F.; Ng, M. K.; Leung, C. W.; Wang G. X., Dendrimer Interior Functional Group Conversion and Dendrimer Metamorphosis-New Approaches to the Synthesis of Oligo(dibenzyl sulfone) and Oligo(phenylenevinylene) Dendrimers, J. Am. Chem. Soc. 2004, 126, 12907-12915.

(23) (a) Kwong, C.-Y.; Leung, M.-K.; Lin, S.-C.; Chan, T.-L.; Chow, H.-F., Synthesis and characterization of oligo(2,7-biphenylenylene-(E)-vinylene)s, Tetrahedron Lett. 1996, 37, 59135916.

(24) Ono, N.; Tomita, H.; Matuyama, K., A New Synthetic Method for Oligo(phenylenevinylenes) Terminated With Porphyrins, J. Chem. Soc., Perkin Trans 1 1992, 2453-2456.

(25) Roncali, J., Molecular Engineering of the Band-Gap of $\pi$-Conjugated Systems: Facing Technological Applications, Macromol. Rap. Commun. 2007, 28, 1761-1775.

(26) Nalwa, H. S. Handbook of Organic Electronics and Photonics, American Scientific Pub., Stevenson Ranch, Calif., 2008.

(27) Ajayaghosh, A., Donor-Acceptor Type Low Band-Gap Polymers: Polysquaraines and Related Systems, Chem. Soc. Rev. 2003, 32, 181-191.

(28) Steckler, T. T.; Henriksson, P.; Mollinger, S.; Lundin, A.; Salleo, A.; Andersson, M. R., Very Low Band-Gap Thiadiazoloquinoxaline Donor-Acceptor Polymers as Multi-tool Conjugated Polymers, J. Am. Chem. Soc. 2014, 136, 1190-1193.

(29) Xu, T.; Yu, L., How to Design Low Band-Gap Polymers for Highly Efficient Organic Solar Cells, Mat. Today 2014, 17, 11-15.

(30) Bundgaard, E.; Krebs, F. C., Low Band-Gap Polymers for Organic Photovoltaics, Solar Energy Mat. \& Solar Cells 2007, 91, 954-985.

(31) Colladet, K.; Fourier, S.; Cleij, T. J.; Lutsen, L.; Gelan, J.; Vanderzande, K.; Nguyen, L. H.; Neugebauer, H.; Sariciftci, S.; Aguirre, A.; Janssen, G.; Goovaerts, E., Low Band Gap DonorAcceptor Conjugated Polymers toward Organic Solar Cells Applications, Macromolecules 2007, 40, 65-72.

(32) Miyashita, T.; Kunisawa, M.; Sueki, S.; Nomura, K., Synthesis of Poly(arylene vinylene)s with Different End Groups by Combining Acyclic Diene Metathesis Polymerization with Wittig-type Couplings, Angew. Chem. Int. Ed. 2017, 56, 5288 -5293.

(33) Yamamoto, N.; Ito, R.; Geerts, Y.; Nomura, K., Synthesis of All-Trans High Molecular Weight Poly(N-alkylcarbazole-2,7-vinylene)s and Poly(9,9-dialkylfluorene-2,7-vinylene)s by Acyclic Diene Metathesis (ADMET) Polymerization Using Ruthenium-Carbene Complex Catalysts, Macromolecules 2009, 42, 5104-5111. 
(34) Paulsen, B. D.; Speros, J. C.; Claflin, M. S.; Hillmyer, M. A.; Frisbie, C. D., Tuning of HOMO Energy Levels and Open Circuit Voltages in Solar Cells Based on Statistical Copolymers Prepared by ADMET Polymerization, Polym. Chem. 2014, 5, 6287-6294.

(35) Jin, Y.; Ju, J.; Kim, J.; Lee, S.; Kim, J. Y.; Park, S. H.; Son, S.-M.; Jin, S.-H.; Lee, K.; Suh, H., Design, Synthesis, and Electroluminescent Property of CN-Poly(dihexylfluorenevinylene) for LEDs, Macromolecules 2003, 36, 6970-6975.

(36) Pechlivanidis, Z.; Hopf, H.; Ernst, L., Cyclophanes, LXII. Paracyclophanes: Extending the Bridges. Synthesis, Eur. J. Org. Chem. 2009, 223-237.

(37) Kim, J.; Heo, M.; Jin, Y.; Kim, J.; Shim, J. Y.; Song, S.; Kim, I.; Kim, J. Y.; Suh, H., Novel 4,7dithien-2-yl-2,1,3-benzothiadiazole-based Conjugated Copolymers with Cyano group in Vinylene Unit for Photovoltaic Applications, Bull. Korean Chem. Soc. 2012, 33, 629-635.

(38) Jin, S.-H.; Kang, S.-Y.; Kim, M.-Y.; Chan, Y. U.; Kim, J. Y.; Lee, K.; Gal, Y.-S., Synthesis and Electroluminescence Properties of Poly(9,9-di-n-octylfluorenyl-2,7-vinylene) Derivatives for Light-Emitting Display, Macromolecules 2003, 36, 3841-3847.

(39) Sohn, B.-H.; Kim, K.; Choi, D. S.; Kim, Y. K.; Jeoung, S. S.; Jin, J.-I., Synthesis and Luminescence Properties of Poly[2-(9,9-dihexylfluorene-2-yl)-1,4-phenylenevinylene] and Its Copolymers Containing 2-(2-Ethylhexyloxy)-5-methoxy-1,4-phenylenevinylene Units, Macromolecules, 2002, 35, 2876-2881.

(40) Pei, J.; Yu, W.-L.; Huang, W.; Heeger, A. J., The Synthesis and Characterization of an Efficient Green Electroluminescent Conjugated Polymer: Poly[2,7-bis(4-hexylthienyl)-9,9dihexylfluorene], Chem. Commun. 2000, 17, 1631-1632.

(41) Leclerc, M., Polyfluorenes: Twenty years of Progress, J. Polym. Sci. Part A: Polym. Chem. 2001, 39, 2867-2873.

(42) Tamaru, S.-i.; Yu, L.; Youngblood, W. J.; Muthukumaran, K.; Taniguchi, M.; Lindsey, J. S., A Tin-Complexation Strategy for Use with Diverse Acylation Methods in the Preparation of 1,9Diacyldipyrromethanes, J. Org. Chem. 2004, 69, 765-777.

(43) Chan, T.-L.; Fong, S.; Li, Y.; Man, T.-O.; Poon, C.-D., A New one-flask Ramberg-Bäcklund Reaction, J. Chem. Soc., Chem. Commun. 1994, 1771-1772.

(44) Burdon, M. G.; Moffatt, J. G., Sulfoxide-carbodiimide Reactions. IV. Acid-catalyzed Reactions of Phenols with Sulfoxides and Carbodiimides, J. Am. Chem. Soc. 1966, 88, 5855-5864.

(45) Söderman, S. C.; Schwan, A. L., 1,2-Dibromotetrachloroethane: An Ozone-Friendly Reagent for the in-Situ Ramberg-Bäcklund Rearrangement and Its Use in the Formal Synthesis of $E$ Resveratrol, J. Org. Chem. 2012, 77, 10978-10984.

(46) Kotha, S.; Khedkar, P., Rongalite: A Useful Reagent in Organic Synthesis, Chem. Rev. 2012, 112, 1650-1680.

(47) Paquette, L., The Base-induced Rearrangement of $\alpha$-Halo Sulfones, Acc. Chem. Res. 1968, 1, 209216.

(48) Meyers, C. Y.; Hua, D. H.; Peacock, N. J., (2,4-Pentadienyl)trimethylsilane: a Useful Pentadienylation Reagent, J. Org. Chem. 1980, 45, 1721-1722.

(49) Jin S-H.; Park, H.-J.; Kim, J. Y.; Lee, K.; Lee, S.-P.; Moon, D.-K.: Lee, H.-J.; Gal, Y.-S., Poly(fluorenevinylene) Derivative by Gilch Polymerization for Light-Emitting Diode Applications, Macromolecules 2002, 35, 7532-7534. 
(50) Song M.; Park, J. S.; Yoon, M.; Yoon, H. W.; Kim, A. J.; Jin, S.-H.; Gal, Y.-S.; Lee, J. H.; Geng, J. W., Synthesis and Characterization of Poly(carbazolyl-2,7-vinylene) Derivatives for Organic Light-emitting Diode Applications, Macromol. Res. 2010, 18, 1088-1095. 
Use for table of content only:

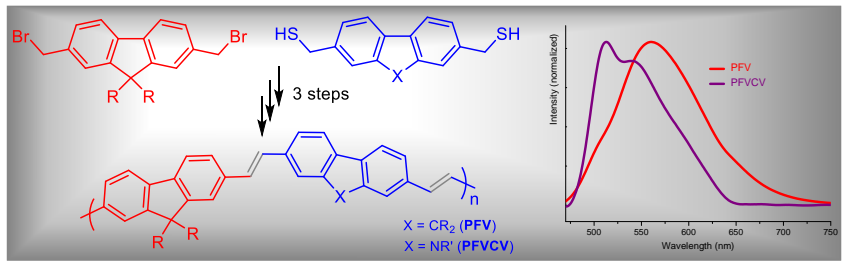

